\title{
Some reflections on representation and embodiment in cognitive psychology and cognitive science
}

\author{
Fatemeh Shafiei $^{{ }^{*}}$, Habibollah Ghassemzadeh ${ }^{2}$ \\ 1- Ph.D. student of Cognitive Sciences of Language. Institute of cognitive science studies \\ (Corrsponding Author) sh.fatemeh1980@gmail.com \\ 2- Ph.D. Developmental / Clinical Psychology Professor, Department of psychiatry, Tehran University of \\ Medical Sciences
}

\begin{abstract}
The discussion about the formation of human`s conceptual and cognitive system has been ongoing throughout history and different theories have been presented in this regard. Among the theories that have been advanced during the last 3 decades, there are some well-known viewpoints that emphasize the role of human embedded information processing in the formation of conceptual and cognitive processes. It is believed that cognition is grounded and cognitive processing depends on the environment on the one hand and the bodily sensorymotor system on the other. Our aim in this article is to review some theories of knowledge acquisition in cognitive psychology and cognitive science as well as modality-specific and the so called amodal systems of knowledge representation in the mind.
\end{abstract}

Keywords: Representation, Embodiment, Modality-Specific Representative Systems, Amodal Representative Systems, Grounded Cognition 


\title{
بحثى دربارهُ بازنمايعى و جسم آكينى در روانشناسى شناختى و شناخت بثروهى
}

\author{
فاطمه شفيعى "، حبيباله قاسمزاده² \\ 1- دانشجوى د كتر اى تخصّصى علوم شناختى زبان يُّوهشكدة علوم شناختى، تهران، ايران. ( مؤلَّف مسئول) ) \\ دئ 09126004756 sh.fatemeh1980@gmail.com \\ 2-د دكتراى تخصّصى روانشناسى رشد / بالينى استاد گروه روانيز شكى، دانشخاه علوم بز شكى تهران
}

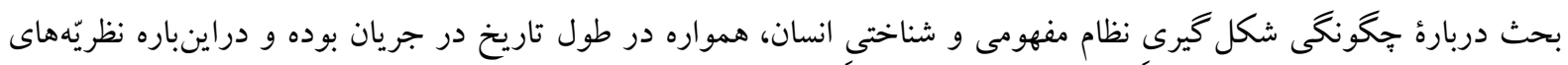

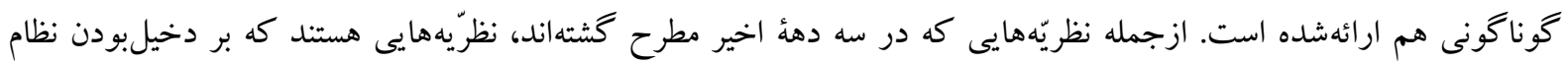

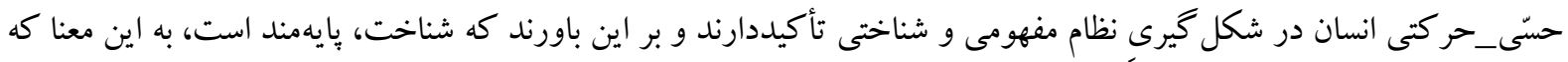

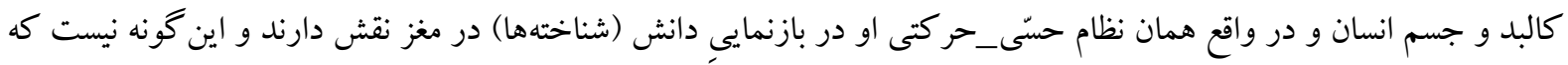

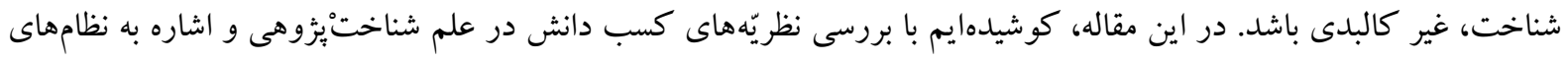

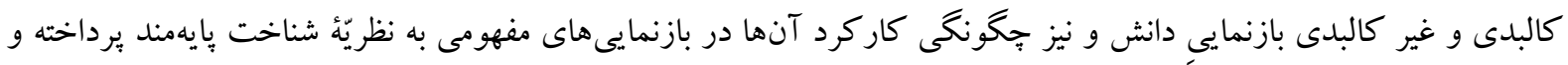

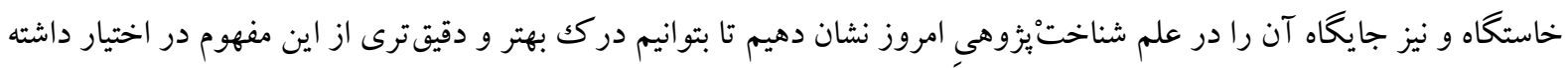

باشيم. كليد وازهها: بازنمايى، جسم آكينى، نظامهاى بازنمايى كالبدى، نظامهاى بازنمايى غير كالبدى، شناختِ پايهمند 
رهگذر، به انواع بازنمايىهايى كه اين دو نظام با خود به همراه مى آورند و به ارتباط آنها با نظرئٌ شناختِ جسم آكين نيز اشاره كنيم. 2. نظريّههاى كسب دانش (شناختهها) در علم شناختيْزوهى

نظام مفهومى، شامل دانش و معرفت افراد از جهان است. در تعريف عام، منظور از دانش (شناختهها) يا

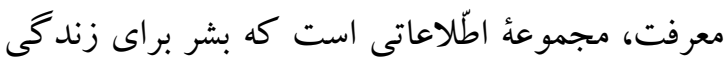
خود از آنها بهره مىبرد. دانش (شناختها)، دربر گيرندهُ تمامى انواع، مراحل و جنبههاى شناخت و آكاهى در عامترين معناى خود است كه از طريق تجربه يا آموزش، كشف يا آموخته مىشود. در بيشتر نظريّههاى مربوط به معرفت، واحد بنيادين، مفهوم منظور مىشود كه خود، موضوعى قابل بحث

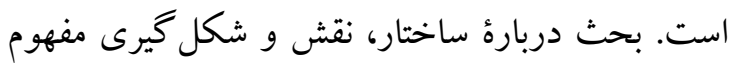
از زمان افلاطون تا به امروز ادامه داشته و دانشمندان علم شناختُِْزوهى نيز امروزه آن را ادامه دادهاند. افلاطونيان بر اين باور بودند كه مفاهيم، به طور مستقل و آزاد از ذهن ها وجود دارند، در حالى كه بيروان فلسفهُ طبيعتنگر، اعتقاد داشتند كه مفاهيم، در حقيقت، بيان روابط علّت و معلولى ميان جهان و ذهن هستند. از اين

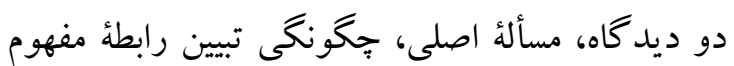
(مقولهاى ذهنى) با پديدههاى جهان عينى است. بسيارى از شناختِيْزوهان و روانشناسان، بر جنبه شناختى اين ارتباط تمركز كردهاند و ساختار، صورت و محتواى بازنمايىهاى مفهومى را مورد ارزيابى قرار دادهاند. آنها مفهوم را به داشتن اطّلاعات دربارهٔ مقوله هاى خاصّى، مانند برند كان، خوردنى ها، نباتات، اثاث، جانوران و غيره تعريف نمودهاند. براى مثال، دانش (شناختهها) دربارهُ مفهوم يرنده، بازنمون داشتن

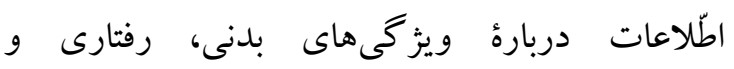

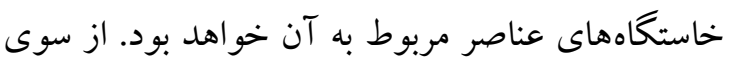

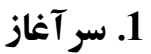

نظام مفهومى انسان، دربر گيرندهُ دانش و معرفتى است

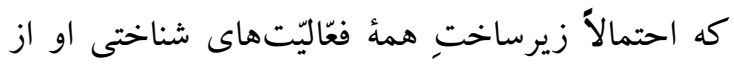

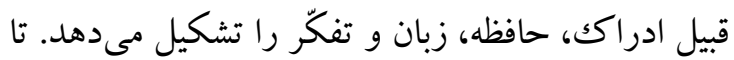

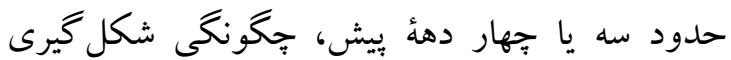
نظام معرفت در انسان، بر مبناى فر آيند يا سازو كارى به يه يه

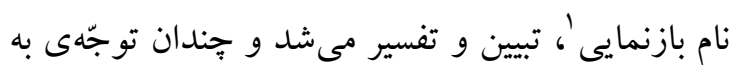
نقش فعّال و جهابسا مستقيم سيستمهاى اختصاصى حسّى_ادراكى در اين شكل گيرى به عمل نمى آمد. امّا،

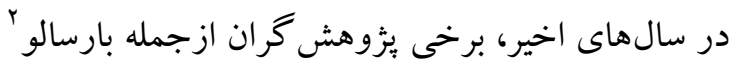

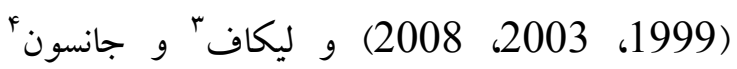
(1980، 1999) مطرح كردهاند كه شناخت اساساً جسم آكينه (ييكرينه و) است: به اين معنا كه يردازش سطوح بالاتر مغزى، ريشه در تجربههاى حسّى و حر كتى انسان دارد. از اين رو، اين بثزوهش كران، وجرود جارجوب مبتى بر تجربهُ حسّى و حركتى را براى

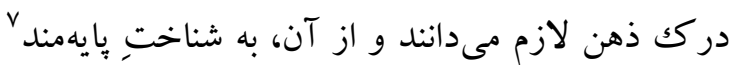
ياد مى كنند (بارسالو، 2008). بر اساس نظريّهاى

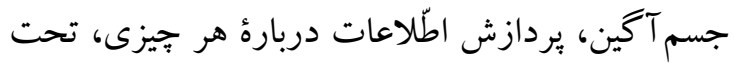

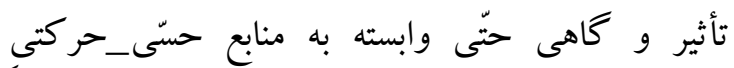

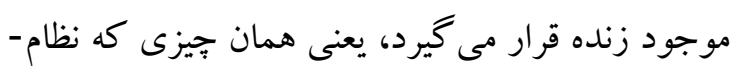

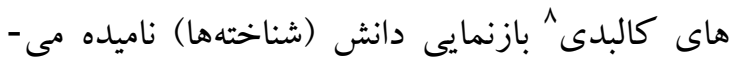

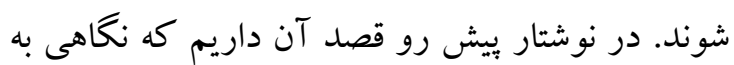

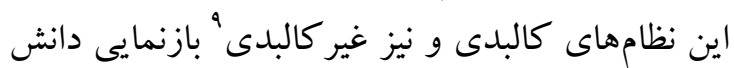
(شناختها) كه وابسته به نمادهاى صورى است، داشته باشيم، ويز گى هاى هر يكك را بررسى نماييم و از اين

\footnotetext{
1- Representation

2- Barsalou

3- Lakoff

4- Johnson

5- Embodied

6- وازٔ بيكرينه، بر گرفته از وازٔه "ييكرينگى " است كه در كتاب زيباشناسى سخن

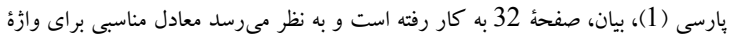
embodiment

7- Grounded Cognition

8- Modality-specific

9- Amodal
} 
بلندمدّت نگهدارى مىشوند، سنگك زيربناى شناخت بشى محسوب مىشوند و از آنجا كه شكلدهنده

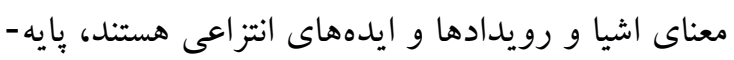

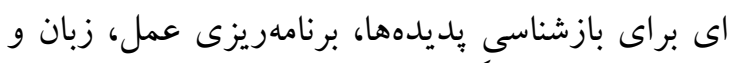

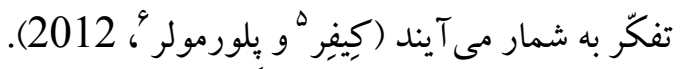

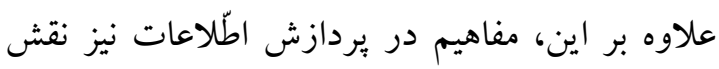

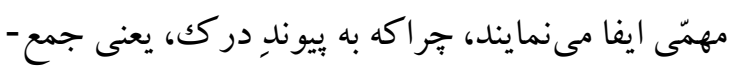

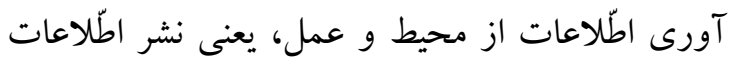

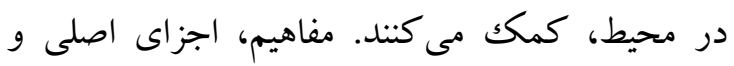
ضرورى معناى كلمه را نيز شكل داده و به اين طريق، دانش معنايى را براى دركى ارتباط كلامى آماده مى -

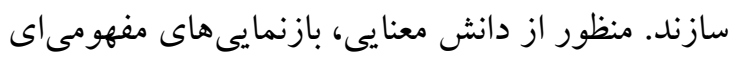
است كه به طور نظام مند به واز كان، اجزاى معنادار آنها، يا ساختهاى متشكل از جند وازه، بيوند خورده

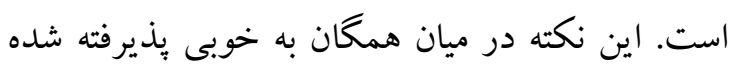
است كه مفاهيم، بازيابى فشردهاى از تجربههاى حسّى و حر كتى ما از محيط هستند كه مقولهبندى شدهاند. در حقيقت، مفاهيم، به مقوله هاى مربوط به اشيا، رويدادها

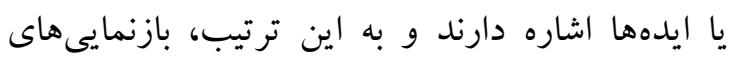
مفهومى نمونهها و موقعيّتهاى خاص را تعميم مىدهند

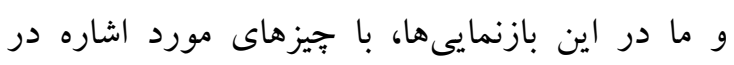
كذشته مواجه مىشويم. از اين رو، مفاهيم در حافظه

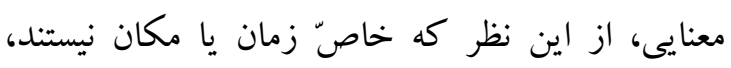
انتزاعى به شمار مى آيند (كِيفِِ و پِلورمولر، 2012)

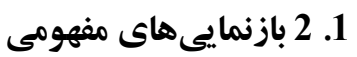
با وجود توافق همكانى بر محتو ایى مفاهيم، بحث ماهيّت بازنمايىهاى مفهومى، همجنان، مطرح است (كِيفِر و

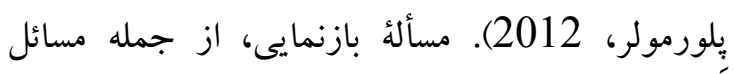
اصلى و مركزى در مطالعهُ حافظه و در كل، شناخت، به شمار مى آيد. : برسشهاى مربوط به اين كه دانش

5- Keifer

6- Pulvermuler
ديخر، شناخت نيز به تعبيرى، عبارت از فر آيند يا كنش

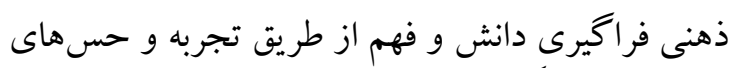
كوناكون، قلمداد شده است. دانش (شناختهها)، در سراسر طيف شناختى، از نقشى مركزى برخوردار است. در بردازش آنى' (برخط) محيط، دانش (شناخته ها)،

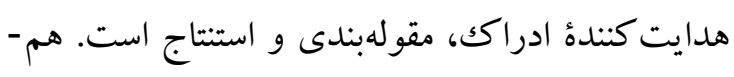

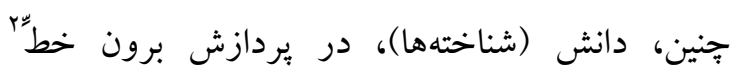

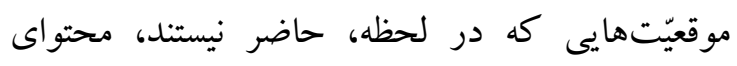
حافظه را بازسازى مى كند و بهعنوان زيربناى معانى عبارتهاى زبانى عمل مى كند و بازنمايىهاى دست -

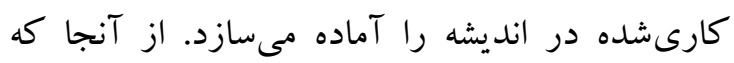
دانش (شناختهها)، نقش مهمى در نظام شناختى دارد،

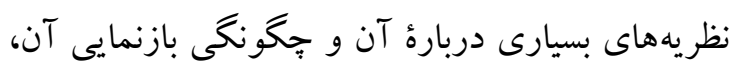

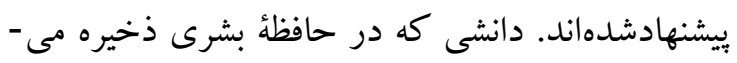

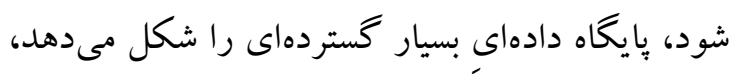

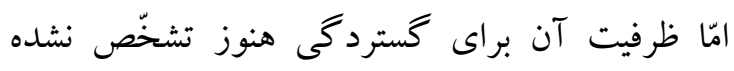

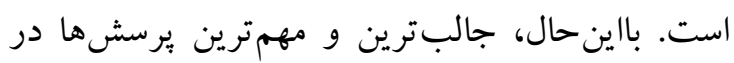

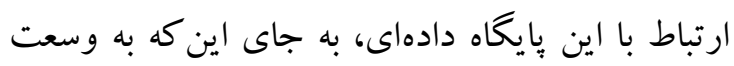

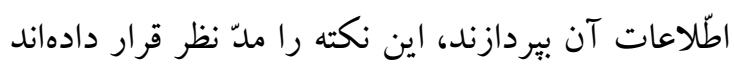
كه جه نوع اطّلاعاتى در حافظه ذخيره مى گردد و و

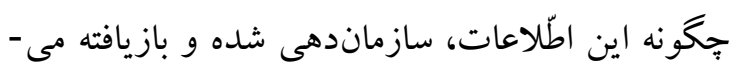

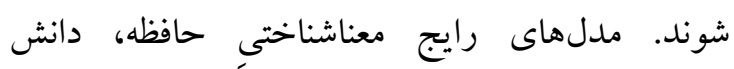

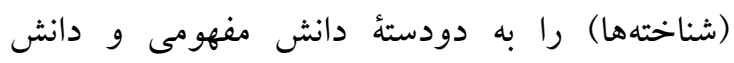
ارتباطى تقسيم مى كنند. در مدلهاى دانش مفهومى، فرض بر اين است كه مفاهيم، واحدهاى بنيادين شناخت را تشكيل مىدهند و يديدهها و رويدادها بر آن اساس بازنمايانده مىشوند و موجب سازمانيابى مقوله -

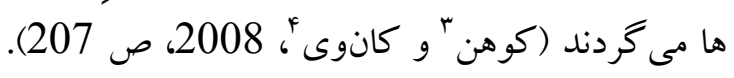

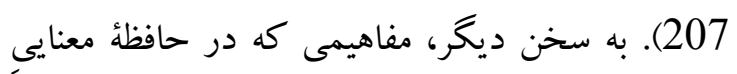

\footnotetext{
1- On-line

2- Off-line

3- Cohen
}

4- Conway 


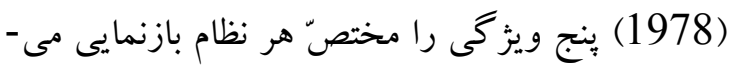

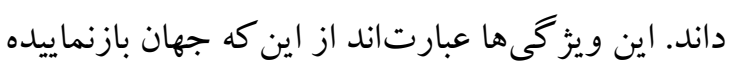
كدام است؟ جهان بازنماينده جيست؟ جه جنبه هايى از جهان بازنماييده در نقش مدل عمل مى كند؟ جه جنبه هايى از جهان بازنماينده در نقش مدل عمل مىنمايد؟ بـ بـ

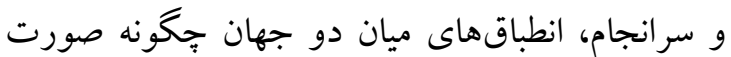

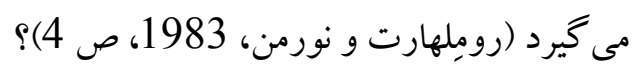
هر جهانى، اعم از بازنماينده و بازنماييده، از مجموعه اي بديدهها و روابط ميان آنها تشكيل شده است و به به به به بهابه هنگام بازنمايى، ويز گیىهاى جهان بازنماييده، به جهان

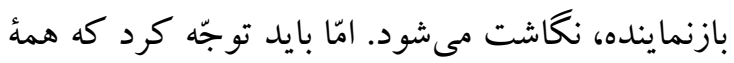

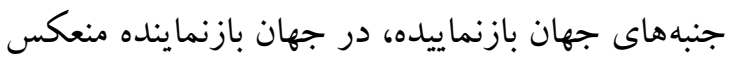

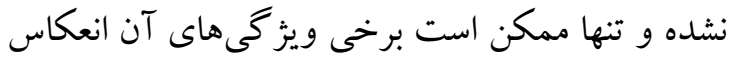
يابد (رومِلهارت و نورمن، 1983، ص 4). از سوى

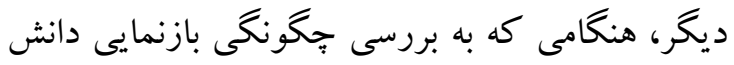

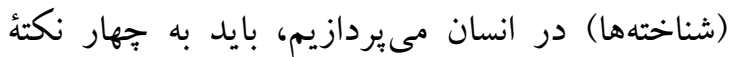

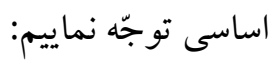
الف. محيطى كه در آن، اشيا و رويدادها وجود دارند. ب. مغزى كه بسته به حالت در جريان آن و اطّلاعات حسّى اى كه به آن داده مىشود، حالتهاى خاصّى را

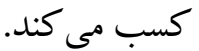
ج. تجربهُ بديدارى فرد كه فرض مىشود تابعى از

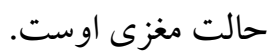
د. داشتن مدل يا نظريّهاى براى آن محيط كه اشيا و رويدادها در آن وجود دارند، حالتهاى مغزى كه در

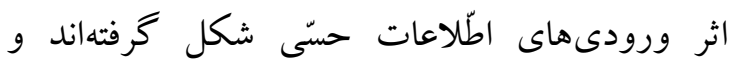
تجربهُ بديدارى فرد.

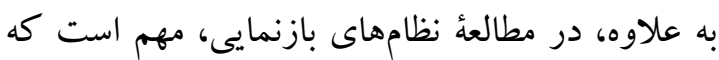
بدانيم جندين جفت جهانهاى بازنماينده و بازنماييده وجود دارند و بر اين اساس، نظريّهاى بازنمايى، در

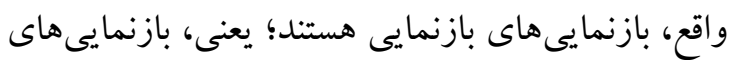

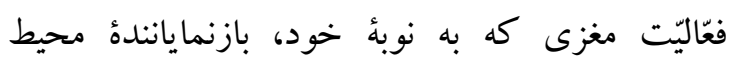

(شناختهها) جه گ گونه ذخيرهشده و به كار گرفته مىشود، در تمامى جنبههاى شناخت واردشده است. بهرغم مر كزىبودن اين مفهوم، يا شايد هم به دليل آن،

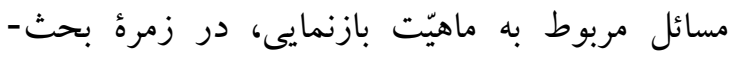

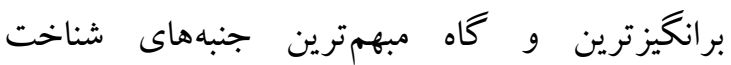

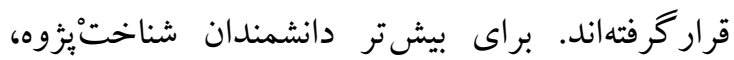
حتّى تصوّر روش شناختِّزْوهىاى كه در آن، نظامى از بازنمايى، نقشى اصلى ايفا ننمايد، به دور از انتظار

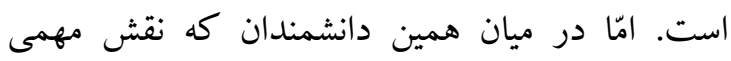
مفهوم بازنمايى را در نظام شناختى بذيرفتهاند، بحثهاى عميقى در باب جيستى دقيق ماهيت بازنمايى در گرفته است:

بازنمايى جِيست؟ آيا بازنمايى، كزارهاى است' يا تمثيلى بَ اصلاً آيا يكك نوع بازنمايى وجود دارد يا باريا

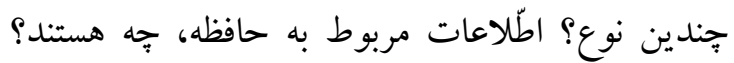
آيا دانشى كه در حافظه نگَدارى مىشود، به گونهاى سازمانبندى مى گردد كه اطّلاعات مرتبط، باهم، ذخيره مىشوند؟ يا اين كه اين ذخيره، به شكل بستهاى

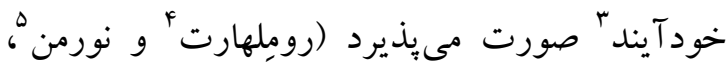

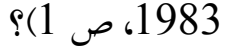
از يك منظر، شايد بتوان گفت بازنمايى جيزى است

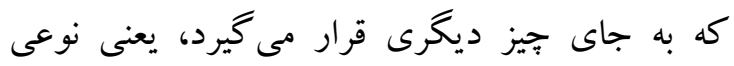

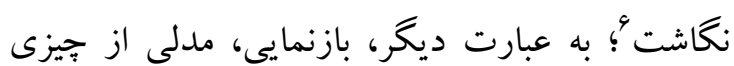

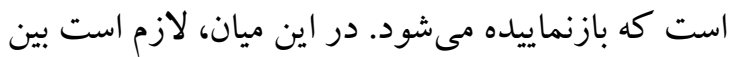

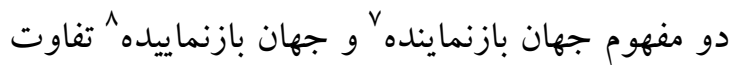
تفاوت قائل شويم. جهان بازنماينده بايد تا حدّى، برخى

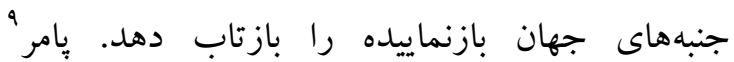

1- Propositional

2- Analogical

3- Automatic

4- Rumelhart

5- Norman

6- Mapping

7- Representing world

8- Represented world

9- Palmer 
به صورت "ابزارهاى روانشناختى" عمل كرده و

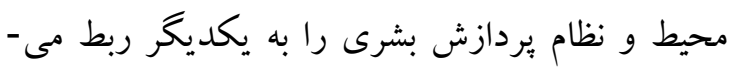
دهند. بر اين اساس، واسطهمندى نيز سازو كارى نشانه شناختى به حساب آمده و از طريق آن، اطّلاعات دريافتى از جهان بيرون و جهان درون پِالايش مىشود

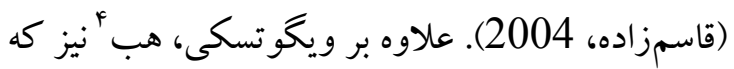
كه يكى از تأثير گذارترين جهرهها در حوزهُ مطالعات روانشناسى در قرن بيستم است، بردازشهاى واسطه-

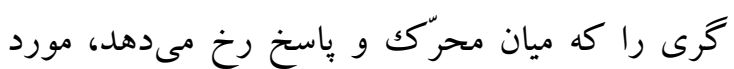

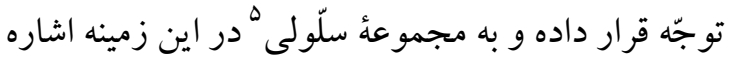
اشاره كرده است. بر اساس نظر هب، فرآيند واسطه -

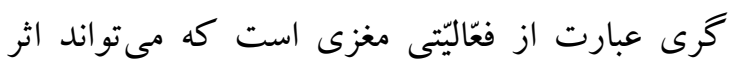

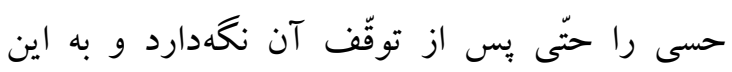

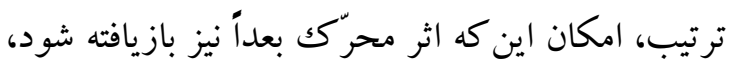

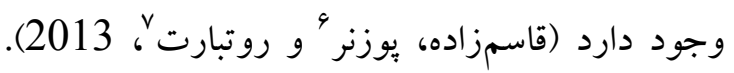

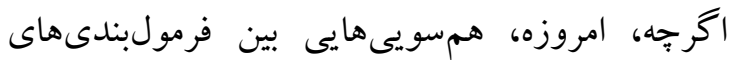

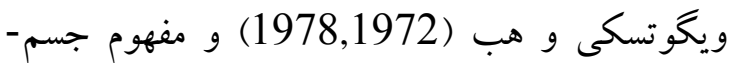
آكينى ^ديده مىشود، از لحاظ تاريخى و تكوينى،

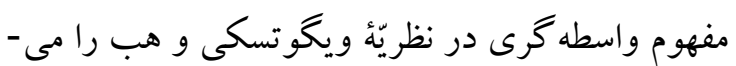
توان با آنجهه رومِلهارت و نورمن دربارهُ بازنمايىهاى واسطهاى بيان كردهاند، همراستا دانست. و سرانجام، به هنگكام مطالعهُ نظامهاى بازنمايى، به اين

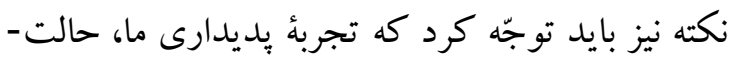
هاى مغزى را بازتاب مىدهد و بنابر اين، مىتواند جهان

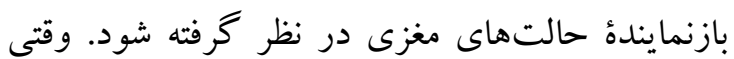
افر اد دربارهٔ بازنمايى مىانديشند، اغلب، به ارتباط ميان تجربههاى بديدارى و محيط فكر مى كنند، امّا در حقيقت، اين ارتباط، ارتباطى دست دوّم است كه به حالتهاى مغزى به عنوان ميانجى و واسطة آن، قرار

4- Hebb

5- Cell assembely

6- Posner

7- Rothbart

8- Embodiment
هستند. از اينرو، مىتوان كفت درون مغز، حالتهاى مغزى وجود دارند كه بازنمايندة محيطاند. محيط ويرامون، جهان بازنماييده و حالتهاى مغزى، جهان

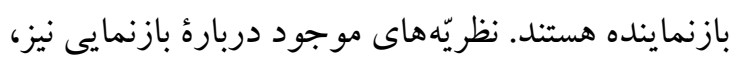
در حقيقت، بازنمايىهاى حالتهاى مغزى هستند و نه

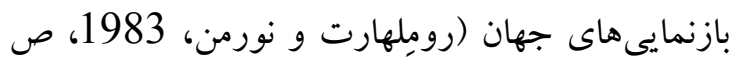
6). براى مثال، زبان به عنوان نظامى متشكّل و سازمانيافته از نشانهها كه جهان را بازمىنمايد، ميان جهان و

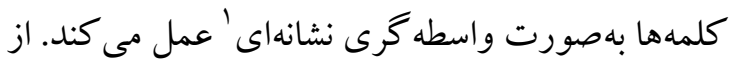
از جمله افرادى كه به نوعى به اين نقش واسطهمندى

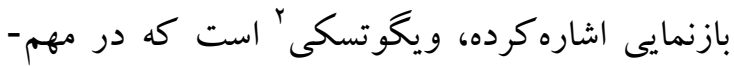
ترين اثر خود، انديشه و زبان، با طرح دوبارهُ مسألهُ زبان

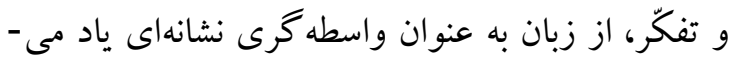
كند و خاطرنشان مىسازد كه كودكك با يادگيرى كلمات به بازنمايى واسطهمندى از جهان نائل مى گردد؛ يعنى جهان در ذهن او از طريق زبان رمز گردانى مى - بـ شود. براى مثال، اكر در كودكك خردسال، ديدن شيشء شير او را به ياد شير مىاندازد، در كودكك بزرگكتر، شنيدن كلمهٔ شير قادر است صورت ذهنى شير را در او

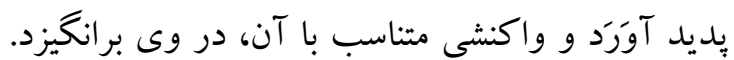
بدين اعتبار، كلمهٔ شير (يا در قالب اصطلاحات

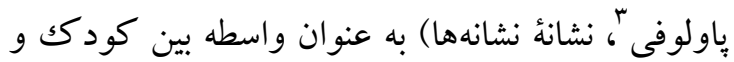
جهان خارج عمل مى كند و شناخت او از جهان، شناختى واسطهمند به حساب مى آيد (قاسمزاده،

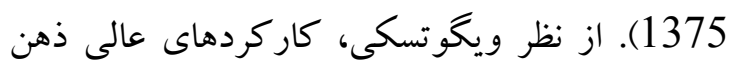
انسان بايد محصول فعاليتى واسطهاى در نظر گرفته شود. او بر اين باور است كه اين واسطه گرى به وسيلة نشانها و نظام نشانهاى كه مهمترين آنها كفتار محسوب مىشود، انجام مى گيرد. منظور از نشانه در

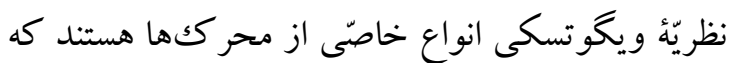

1- Semiotic mediation

2- Vygotsky

3- Pavlov 
مقولههاى ذاتى قرار دارند، يا از طريق استدلال "شكل

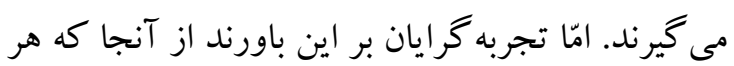
دانش معنادارى، درنهايت، از طريق تجربئ حس_بنياد فرد به دست مى آيد، مفاهيم مبتنى بر استدلال نمى -

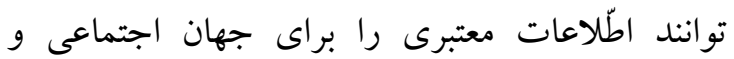

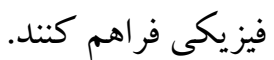
براى اين كه بحث را در متن عصبْشْناختى قرار دهيم،

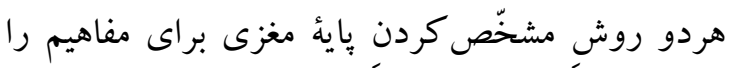
بررسى مى كنيم. در هر دو رويكرد خردگرا و تجربه - هردئ

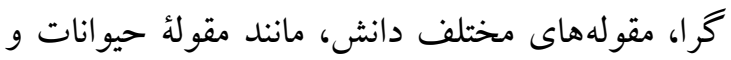
مقولة ابزار، از يايه و بنياد با هم متفاوتاند. در نخاه

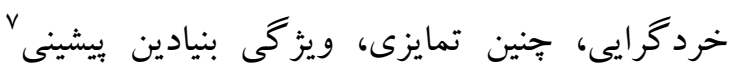

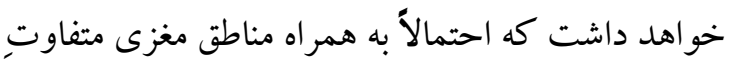
مسئول براى بردازش هاى مختص به هريكك است. امّا از ديدگاه تجربه گرايى، تفاوت مقولهها، از تجربهُ حسّى __حركتى متفاوت ناشى مىشود: حيوانات از اطّلاعات مربوط به شكل و ويز گیىهاى ظاهرىشان شناخته مى -

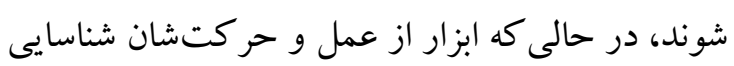
مى گردند (كِيفِ و پِلورمولر، 2012)

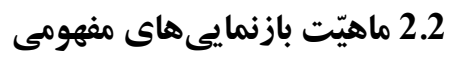

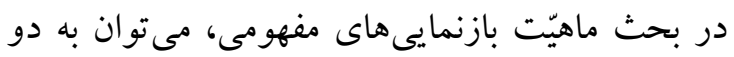
نظام بازنمايى مهم كه در علم شناختُْيزوهى همواره مورد بحث بودهاند، نام برد (رومِلهارت و نورمن،

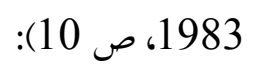

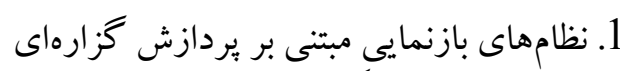

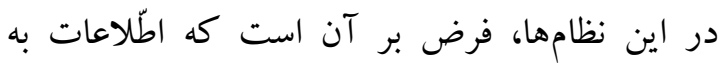

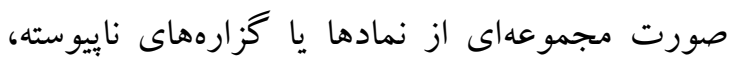
بازنماييده مىشوند به كونهاى كه مفاهيم موجود در جهان، از طريق عبارتهاى صورى بازنمون مى گردند. اغلب نظامهاى بازنمايى كه تا كنون گسترش يافته و

6- Reasoning 7- A priori
دارد، اخرجه، به ندرت، به طور صريح، در نظريّههاى

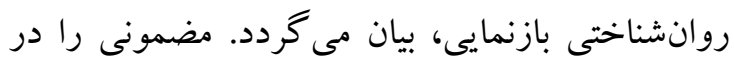
نظر بخيريد كه در آن، تجربه يديدارى ما، جهان خارج

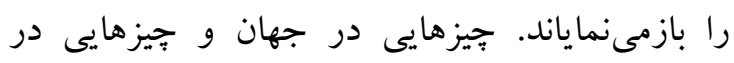
تجربه وجود دارند. جيزهاى تجربهُ ما با جيزهاى جهان يكسان نيستند، امّا به نظر مىرسد بخش اعتر اعظم ساختار جهان را منعكس مى كنند. به اين طريق، صحبت دربارهٔ بازنمايى تجربى ما از جهان، معنى دارد (رومِلهارت و و

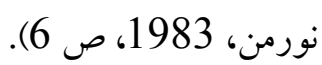
نكته ديخرى كه در بحث بازنمايىها مطرح بوده و بحث هاى زياد و گاهى متناقض، درباره آن در گرفته، نقش بازنمايى حسّى_حر كتى در ساخت مفاهيم است. اين بحث، به حدود 2000 سال قبل و به زمان يونان

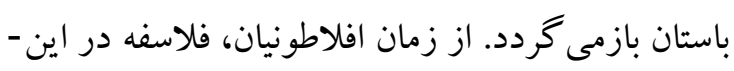

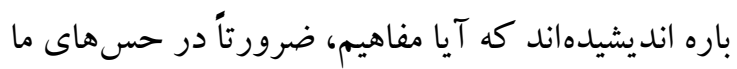

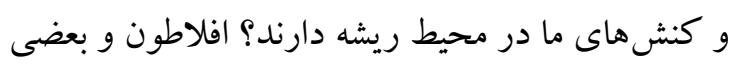

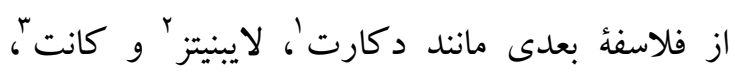
نسبت به اين مسأله بسيار ترديد داشتهاند. بر اساس

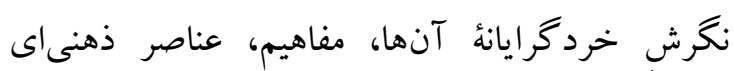
هستند كه به طور بنيادين، از حسهاى جسمى جدا بوده آنها، و حتّى بيشنيازى نيز براى آنها به حساب مى آيند. در

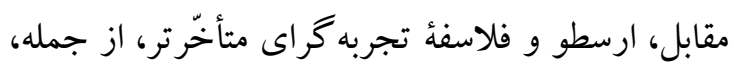

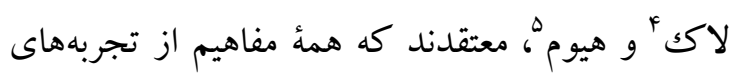
جسمى ناشى شده و در واقع، نسخهُ تلخيصشده همان حسها و تجربهها هستند. از ديد گاه فيلسو فان خرد گر ا، مفاهيم نمى تو انند حسها هـا را منعكس كنند خراكه ادراكى، آنقدر بدون ساختار است كه قادر به فراهم نمودن پايهاى معنادار براى مفاهيم نيست. اين فيلسوفان مى گويند مفاهيم يا بر باية

1- Descartes

2- Leibnitz

3- Kant

4- Locke

5- Hume 
رومِلهارت، بحث بازنمايىهاى تمثيلى را با مواردى

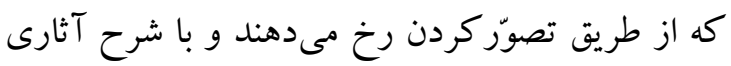

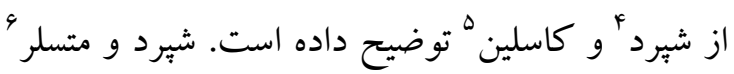
متسلر ( (1971)، جفتهايى از اشياى سهبعدى را كه ونه بعضى از آنها با يكديخر متفاوت و برخى ديخر، با

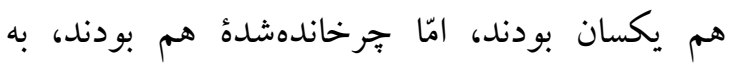

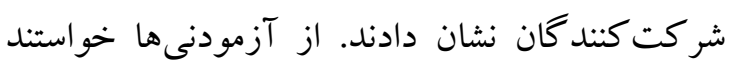
اين جفت تصاوير را ارزيابى كنند و بكويند آيا آن تصاوير مشابه هستند يا خير. سبس، در حين پِاسخدادن،

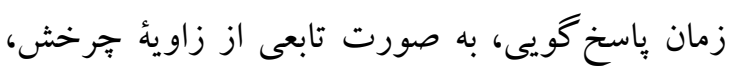
در يكك نمودار ترسيم شد. شيرد و متسلر مشاهده كردند كه هرقدر تفاوت زاويهاى، بين دو شكل بيشتر باشد، تمدرد ياسخدادن به آن، زمان بيشترى مىبَرد. بر اين اساس،

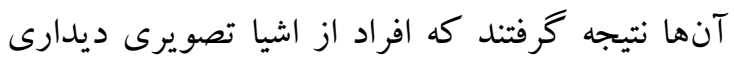
مى سازند كه بر يائ يكى از دو تصوير موجود است و

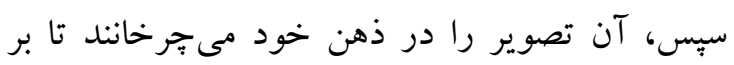
تصوير ديخر منطبق شود. به سخن ديخر، شيرد و متسلر، فر آيند جرخاندنِ ذهنى شىء را مستلزم به كارگيرى تمثيل (قياس) ذهنى جهت فيزيكى دانستند (روملمهارت و نورمن، 1983) - (1983). يكى ديخر از بهترين نظريّهايى كه دربارهُ بازنمايى

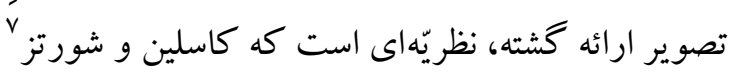

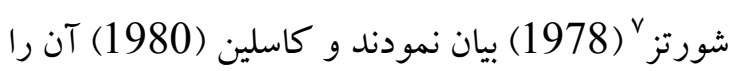
را مورد بازنخرى قرار داد (رومِلهارت و نورمن، 1983). اين نظريّه، از يك سو، نظريّهاى كاركردى بـ است، يعنى شرح مى دهد مغز ما با تصاوير جه مى كند؛ و از سوى ديخر، نظريّهاى عمومى محسوب مى شود كه تلاش مى كند براى عمليّات مختلفِ دخيل در بردازش تصاوير، توجيهى به دست دهد؛ درست برعكس نظريّه

4- Shepard

5- Kosslyn

6- Metzler

7- Schwartz
مورد ارزيابى واقع شدهاند، بازنمايىهاى گزارهاى بودهاند. اين نظامهاى بازنمايى، همكى در اين ويز كى

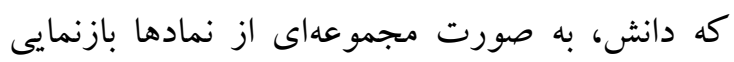

$$
\text { مى شود، مشتر ك هستند. }
$$

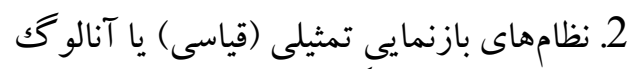
در نظامهاى بازنمايى تمثيلى، انطباق يا نغاشت ميان جهان بازنماييده و جهان بازنماينده، هرجه مستقيمتر

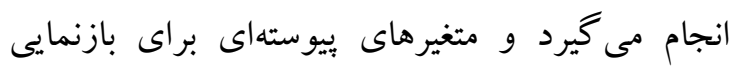
مفاهيمى كه در جهان واقعى نيز بيوسته هستند، به كار برده مىشود. به عنوان مثال، مىتوان به نقشههايى كه بازنمايىهاى تمثيلى برخى ويز گیىهاى جغر افيايى جهان

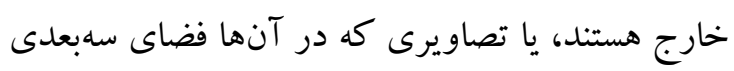
از طريق نشان گذارىهايى بر صفحهُ دوبعدى بازنمايى ئري

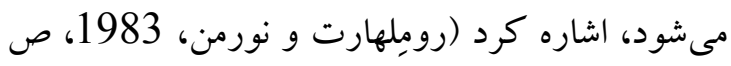

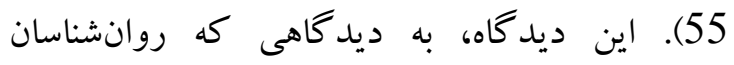
كشتالت دربارهُ بازنمايىهاى ذهنى دارند، نزديك ديك است. روانشناسان گشتالتى، بر اين باورند كه بين

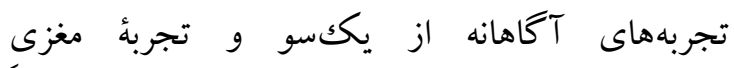

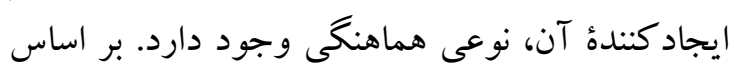
اين ديدگاه كه همريخت گرايى 'بين عين و ذهن ناميده

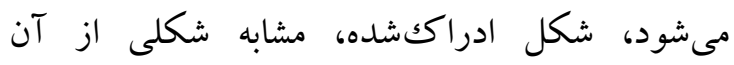
مجموعه سلّولهاى مغزى است كه وظيفهُ حركت آن

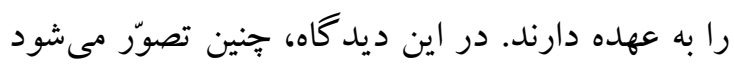
كه بازنمايىهاى ذهنى عناصر و ميدانهايى كه بر آنها عمل مى كنند، (فر آيندهاى قشر مغز مانند ميدان، عمل

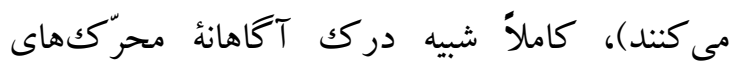
ورودى هستند، مانند همان مثال نقشهُ تمثيلى منطقه

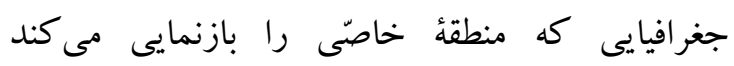

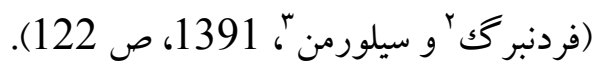


و دگر گونى' تصوير مىداند. تشكيل تصوير در حافظهٔ

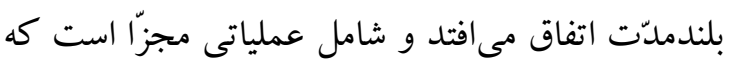
هركدام از آنها با دستور جداكانهاى انجام مىشود. كاسلين، خاطرنشان مىسازد كه تصاوير، به تدريج شكل مى گيرند و از اينرو، تصاويرى كه اجزاى بيش - مانس ترى دارند، زمان بيشترى براى شكل گيرى شان نياز است. جستوجوى تصاوير نيز هنگامى رخ مىدهد كه برى از ما دربارهُ تصويرى سؤال برسيده مىشود. جستوجو، شبيه نغاه كردن به تصوير با جشم ذهنى است. كاسلين، نشان داده است كه ما مىتوانيم به عنوان بخشى از فر آيند جستوجو، بر تصوير متمركز شويم يا

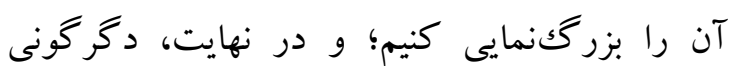
تصوير به عمليّاتى گفته مىشود كه بر تصوير صورت مى گيرد و تغييرى در آن ايجاد مى كند. كاسلين دو

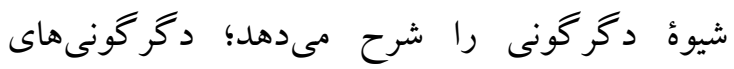

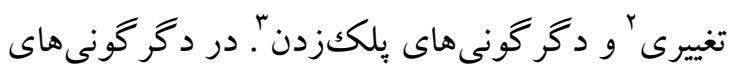
هاى تغييرى، تصوير بلصورت فزايندهاى از نظر اندازه،

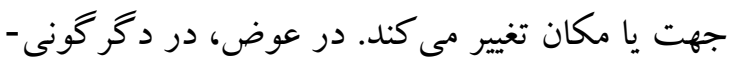
هاى بِككزدن، كل" تصوير به صورت يك يكجا تغيير كرده و به طور كامل از نو ساخته مىشود (فردنبر گك و

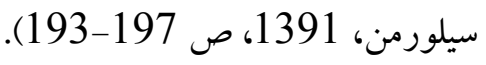
برواضح است كه توانايى انسان در تصوّر كردن كسترهُ

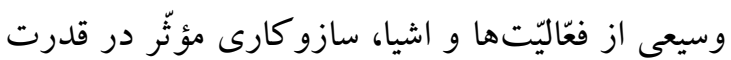
او براى استدلال كردن دربارهُ جهان محسوب مى شود. با سلا

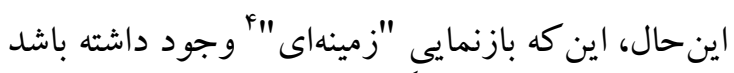
باشد كه قالب بازنمايى مفيدى براى اغلب تصوّرات

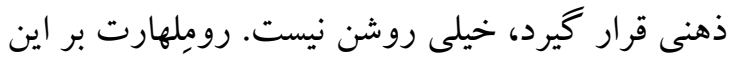
باور است كه بايد به جاى "تصوّر ذهنى" از "مدل

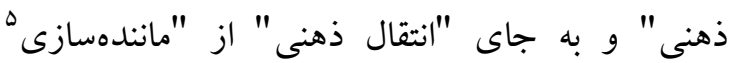

1- Transformation

2- Shift transformation

3- Blink transformation

4- Matrix

5- Simulation
اختصاصىاى مانند جرخش ذهنى تصاوير كه بيش از اين ذكر شد و در آن، تنها بر عمليّات خاصّى تأكيد شده بود. كاسلين، براى توصيف نظريّهُ خود، ميان ساختارهاى درگير در تصويرسازى ذهنى و فر آيندهايى برون كه بر اين ساختارها عمل مى كنند، تمايز قايل شد. او دو نوع ساختار تصوير را فرض كرد. يكى بازنمايى سطحى بـ كه شبهتصويرى است و در يكك واسطة فضايى اتِفاق مى افتد و ديخرى، بازنمايى عميق كه شامل اطّلاعات

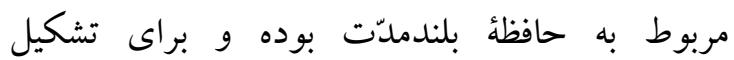
بازنمايىهاى سطحى مورداستفاده قرار مئى ميرد.

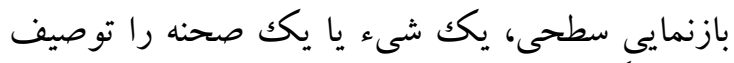

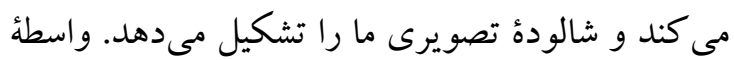

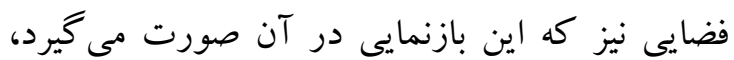

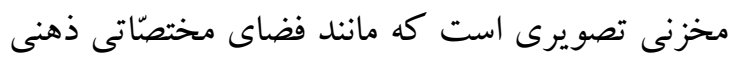
عمل مى كند و اندازهُ محدود و شكل ويزٔهاى دارد. بازنمايىها در اين مخزن براى مدّت كو تاهى مىمانند. اين بازنمايىها، بيشتر، شبيه تصويرى هستند كه بر

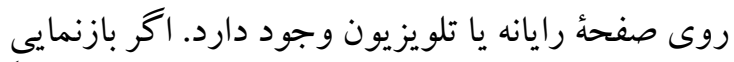
مخزن تصويرى، دوباره تكرار نشود، به زودى محو روني خو اهد شد. بازنمايىهاى عميق، دوّمين نوع از ساختار تصوير را تشكيل مىدهند كه شامل دو نوع رمز گذارى

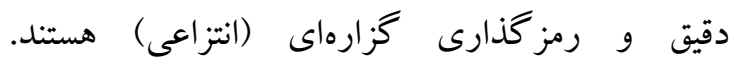
رمز گذارى دقيق، فهرستى از جزئيّاتِ مختصّات مربوط

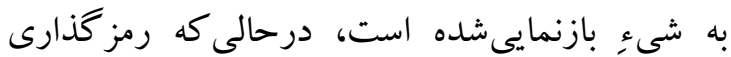

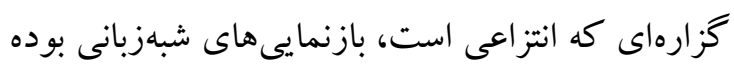
و جملههاى خبرىاى را شامل مى شود كه اطّاعاتى را دربارة اجزاى يك شىء، مكانيابى آن و اندازهاش فراهم مىنمايد. علاوه بر ساختارهاى سطحى و عميق تصوير، كاسلين، فر آيندهايى را نيز كه بر اين ساختارها عمل مى كنند، مورد توجّه قرار داده است. او اين فر آيندها را شامل تشكيل تصوير، جستوجوى تصوير 
ولى ارتباط بازنماييده اين گونه نباشد، بازنمايى اختيارى است و از اين رو، هر ساختارى كه ارتباط بازنماينده داشته باشد، بر بازنماييده تحميل مى گردد.

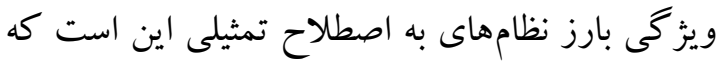

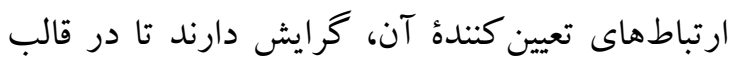
بازنمايى، ذاتى شوند. امّا در نظامهاى بازنمايى كزارهـ اى، مشخّصهاى ذاتى ارتباطهاى بازنماينده، مشخّصههاى جيزهاى بازنماييده نبوده و بنابراين، بايستى به بازنمايىها به صورت محدوديّتهاى عَرَىى و افزوده، اضافه شود. با وجود اين، بايد توجّه كرد اينكه آيا مجموعهاى از محدوديّت ها ذاتى است يا عَرَضى، هيج تفاوتى در عمل نظام بازنمايى ايجاد نمى كند. جيزى

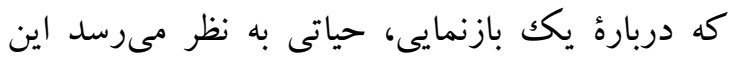
است كه آن، برخى جنبههاى گزيده از جهان بازنماييده

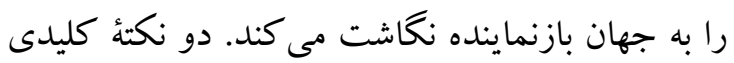
در فهم تفاوتهاى ميان بازنمايىها وجود دارد: اوّل اين كه انتخاب كدام ابعاد جهان بازنماييده قرار است درون جهان بازنماينده ثبت و ضبط گرددد؟ و ديخر، تعيين اينكه جههونه ابعاد انتخابشده، بازنماييده خواهند شد؟ اين دو جنبة تصميم گيرى، يعنى كدام و جه گونه، بر خواص نظام بازنمايى حكومت دارند و و

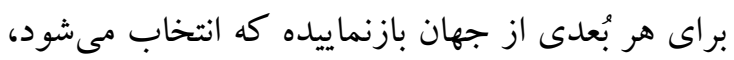

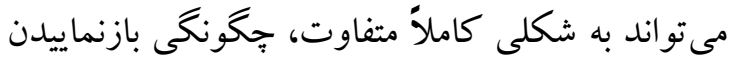
آن وجود داشته باشد (روملهارت و نورمن، 1983،

در بررسى و طبقهبندى بازنمايىهاى مفهومى، كِيفِر و يلورمولر (2011) نيز به جهار بُعد اشاره كردهاند و

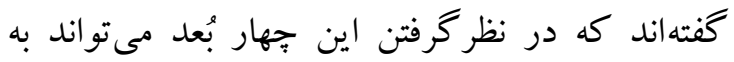
طبقهبندى نسبتاً كاملى از بازنمايىها منجر شود. در ادامه، به اين ابعاد و بازنمايىهاى حاصل از لحاظكردن آنها، اشارهُ كو تاهى خواهد شد البته در برخى موارد،
ذهنى" استفاده كرد. جر اكه به نظر مىرسد انسان در ساخت بازنمايى اشيا و رويدادها به صورت مانندهازى ذهنى، توانايى قابل توجّهى دارد (رومِلهارت و نورمن،

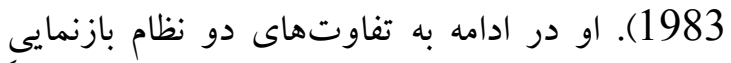

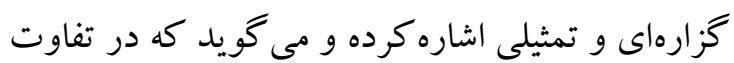
اين دو نظام، سخنهاى بسيار رانده شده است. امّا ما بر اين باوريم كه اين تفاوتها به ميزان زيادى اغراق آميز

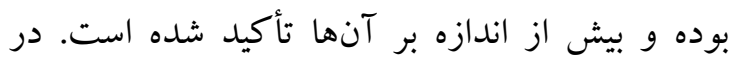

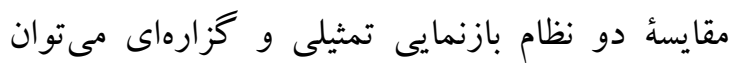

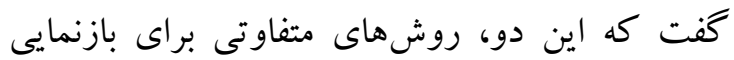

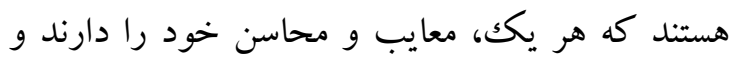
براى شرايطى خاص مناسباند. بر اين اساس، به نظر

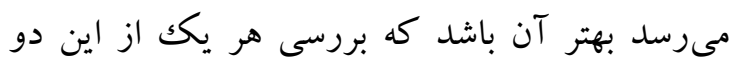

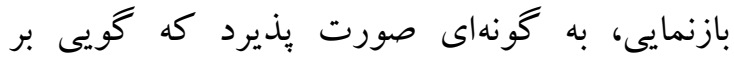

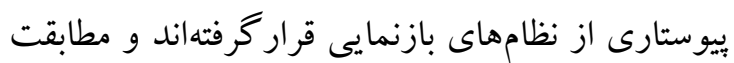

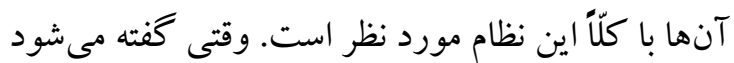
كه يكك بازنمايى، تمثيلى است، به جه معناست؟ به به يك

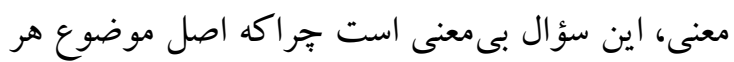

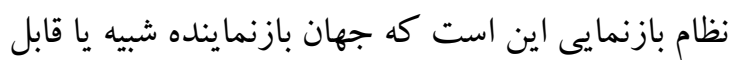
قياس با جهان بازنماييده است.

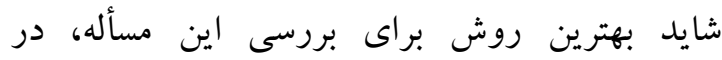

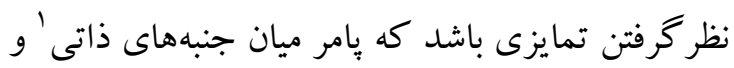

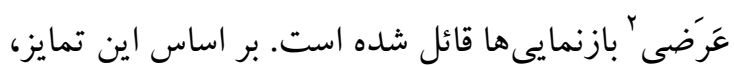
هر زمان كه ارتباط بازنماينده با ارتباط بازنماييده،

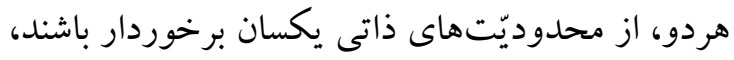

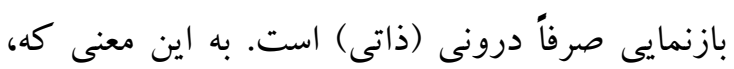
ساختار منطقى كه در ارتباط بازنماينده موجود است، ذاتى خود ارتباط است و نه ساختارى كه بخواهد از بيرون بر آن تحميل شده باشد. از سوى ديگر، آن گاه

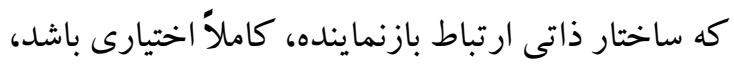


شبكه را فعال مىسازد. ويزّى سوم، ميان نظريّههاى بازنمايى مفهومى كه شكل گيرى مفهوم را ضرورتاً به

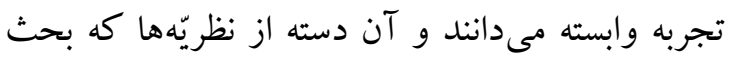
ذاتى بودن و بيشينىبودن را بيش مى كشند، تمايز قائل مىشود. اين تمايز، همان است كه بيش از اين، در بحث روى كردهاى خردگرايى و تجربه گرايى به آن آن اشاره شد؛ و درنهايت، ويز گى آخرى كه مى تواند درد طبقهبندى و بيان ماهيّت بازنمايىهاى مفهومى اثر خذار

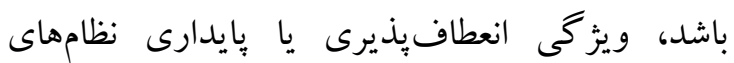
مفهومى است. نظريّهايى كه فرضشان بر بازنمايىهاى

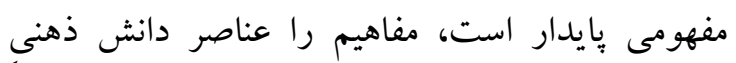
نامتغيّر در نظر مى گيرند. درحالى كه در روى كردهاى مبتنى بر بازنمايىهاى مفهومى انعطاف يذير، به مفاهيم

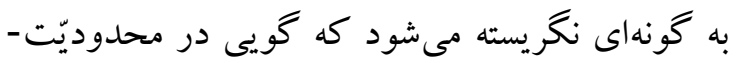
هاى متنى موجود، عناصرى منعطفاند، جون مفاهيم

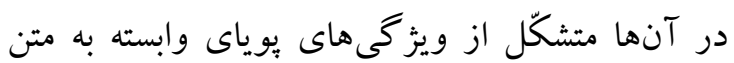

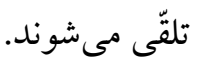
جهار ويز گىاى كه ذكر آن رفت، در طبقهبندى و ارزيابى روى كردهاى نظريّهاى بازنمايى مفهومى مى -

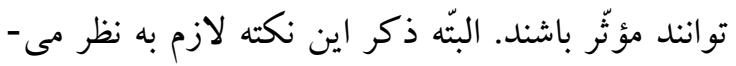

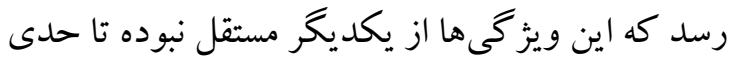
به هم وابسته هستند. براى مثال، نظريّهاى كه مبنايش را بازنمايى مفهومى انعطافيذير قرار مىدهد، مسلّماً

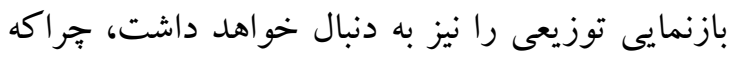

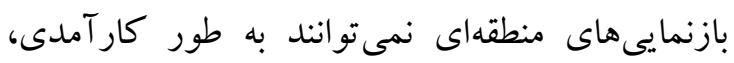
انعطاف يذيرى را به خدمت گيرند. 3. كالبدى بودن: مقدّملاى بر شناخت جسم آكين

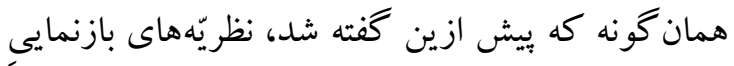

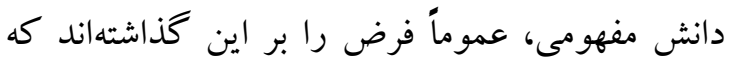

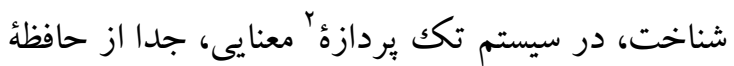
رويدادى و نظامهاى كالبدى، براى ادراك، كنش و
اشتراككهايى با آنجه يِش از اين، از رومِلهارت نقل شده بود، ديده ميىشود.

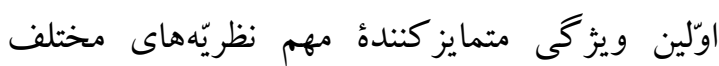

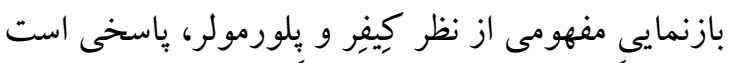

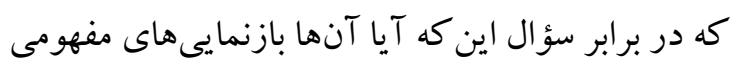

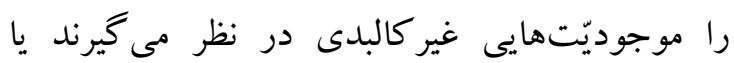

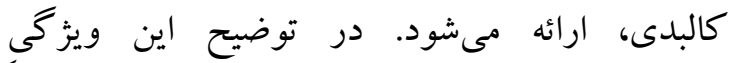
متمايز كننده مىتوان كفت نظريّه ارهاى غير كالبدى، فرض را بر اين مى كذارند كه بازنمايىهاى مفهومى، اساساً، از بازنمايىهاى نظامهاى حسّى_حر كتى در مغز

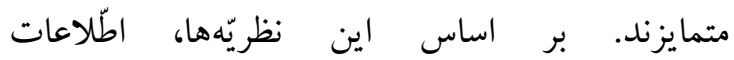

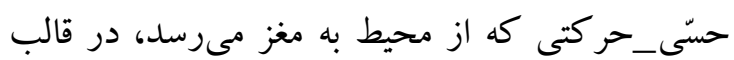
بازنمايى نمادين غير كالبدى تغيير شكل مىدهد و فاقد

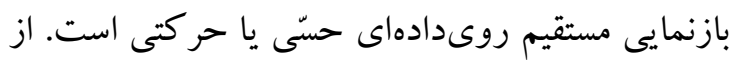

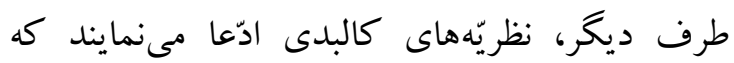
بازنمايى هاى مفهومى، جهه از نظر كاركردى و جهه به

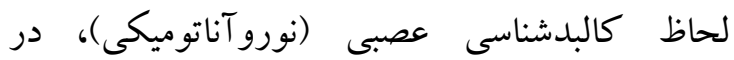
بازنمايىهاى حسّى_حركتى بايه داشته و از طريق آنها شرح داده مىشوند. اين همان وجهى است كه در بحث بـث

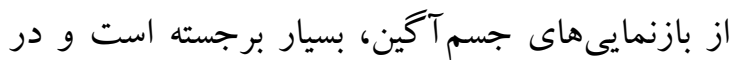
بخش بعدى نوشتار بيش رو، به آن برداخته خو اهد شد.

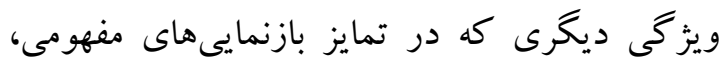

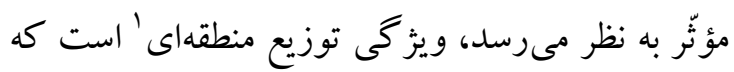
به ساختار درونى بازنمايى هاى مفهومى اشاره دارد و در

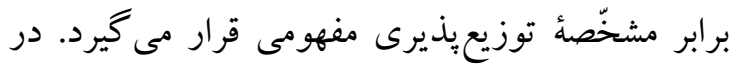

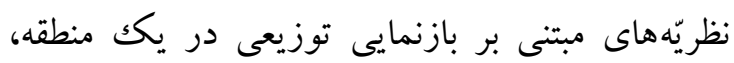

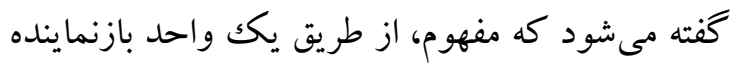

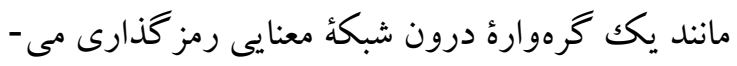

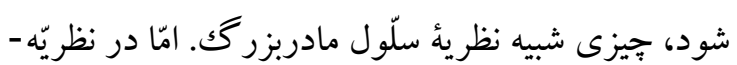
هاى توزيعيذيرى، هر مفهوم با واحدهاى بازنماياننده

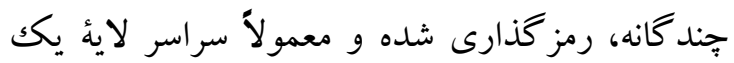

1- Local distribution 
در مقابل، ريشهُ عدم هم گرايى ادراك و شناخت را در

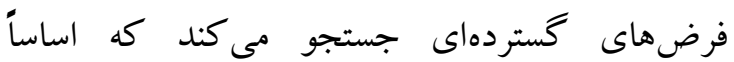
غير ادراكى هستند. او آنها را غير كالبدى نام مىدهد.

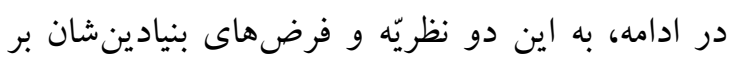

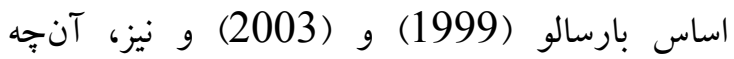
بارسالو (2008)، در مقابل نظريّهاى معيار شناخت،

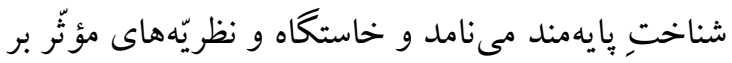

$$
\text { آن، ناهى خو اهيم داشت. }
$$

\section{3 نظريّههاى غير كالبدى بازنمايي دانش (شناختهها)}

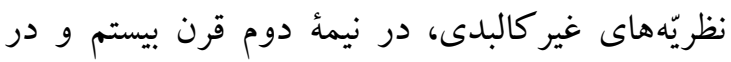
ادامهُ انقلاب شناختى به طور فزايندهاى گسترش يافتند. در واقع، اين نظريّها تا حدّ زيادى منعكس كنندهُ

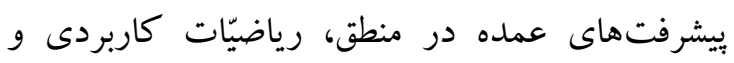
زبانهاى برنامهنويسى در ابتداى قرن بيستم بودند.

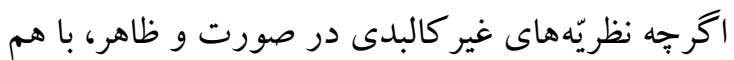
تفاوت بسيارى دارند، همكى آنها در اصلى بنيادين، به

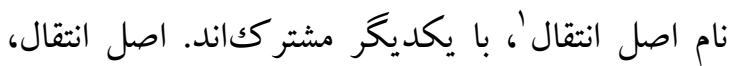

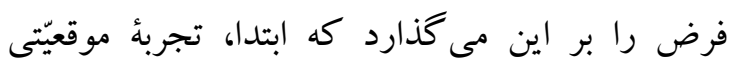
درككشه، بازنمايىهايى را در نظامهاى كالبدى توليد

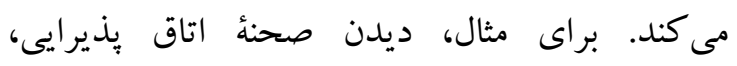
بازنمايىهاى ديدارى را در نظامهاى فضايى و ديدارى مغز براى جيزهاى درك شده، توليد مىنمايد. نشستن بر صندلى و حسكردن آن، برنامهاى حركتى و بازنمايىهاى لامسهاى را در نظامهاى حسّى_حركتى، فعّال مىسازد. موسيقى بخششده در يكى استريو، بازنمايىهاى شنيدارى را در نواحى مختلف شنيدارى مغز، ايجاد مى كند. باسخخهاى هيجانى به موسيقى نيز بازنمايىهايى را در نظامهاى هيجانى_عاطفى مغز نظير

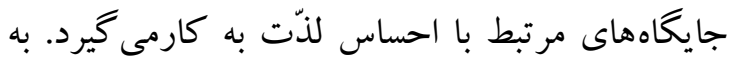
همين ترتيب، ممكن است حالتهاى درونى ديخرى

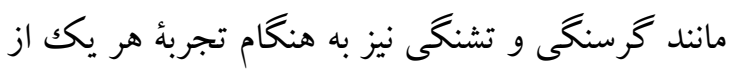

1- Transduction
هيجان قرار دارد. در اين نظريّها، همجزنين، فرض مى شود كه شناخت از نمادهاى غير كالبدى و اختيارى تشكيل شده، به طورى كه بازنمايىهاى مفهومى، غير كالبدى و بر اساس اصول گوناكونى عمل مى نمايند. امّا نظريّههايى هم وجود دارند كه بر بر بر اين باورند بازنمايىهاى مفهومى، كالبدى هستند و در حسّهاى مختلف مغزى بايه دارند. نكتهُ جالب آن كه اين نظريّهها با كسترش و رشد فزايندهاى همر اه بودهاند. نظريّههاى معيار شناخت، فرض را بر اين كذاشتهاند كه شناخت در نظام حافظةٌ معنايى، به طور جداكانه از نظامهاى كالبدى براى ادراك؛ از قبيل بينايى، شنوايى،

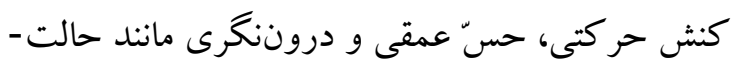
هاى ذهنى و درونى، بازنمايى مىشود. بر اساس اين

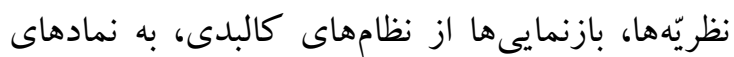

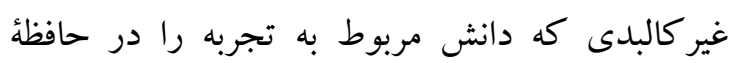
معنايى بازمىنمايند، منتقل مىشوند و دانش و معرفتى

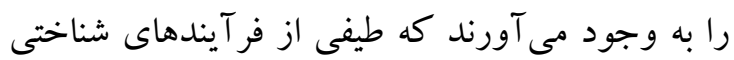
را، از ادراكى گرفته تا انديشه، حمايت مى كند.

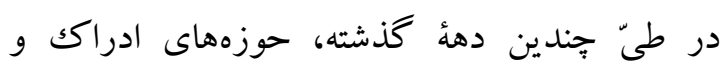
شناخت، نسبتاً واگرا از هم عمل نمودداند، به گمونهاى

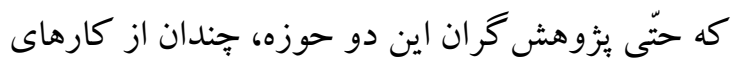
يكديخر آكاه نبودند. يكى از نتايج اين واكرايى، آن

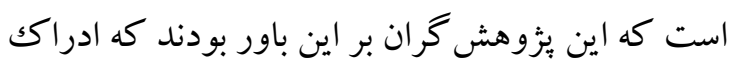

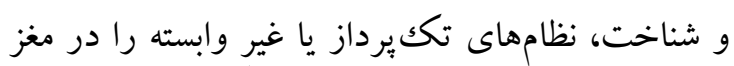

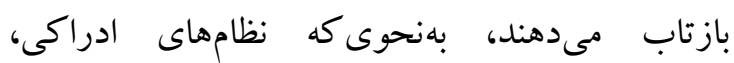

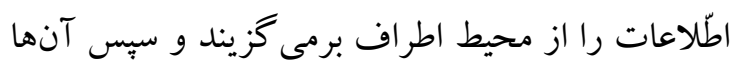
را به نظامهاى جداكانهاى كه از كار كردهاى شناختى

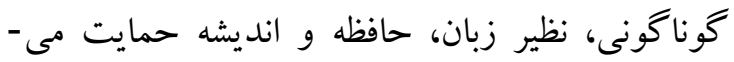
نمايند، انتقال مىدهند. بارسالو، در مقالههاى متعلّد

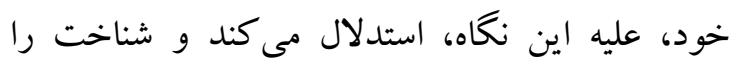

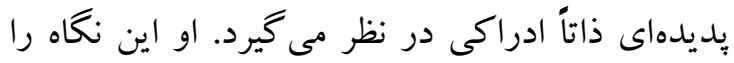

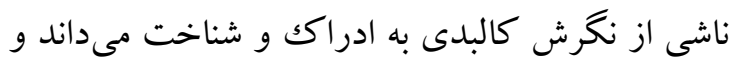


و سبس، اين نمادها را با به كاربردن وازمهاى مرتبط با

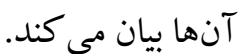
در نظريّهاى غير كالبدى بازنمايى دانش (شناختهها)،

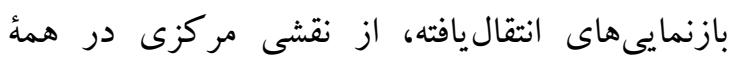

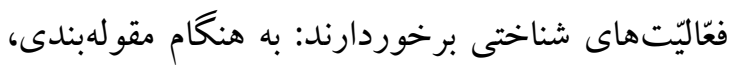

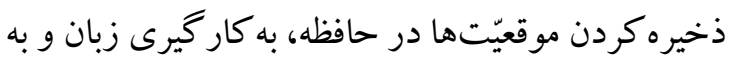
هنگام انديشيدن، نمادهاى غير كالبدى، مقولهها را باز

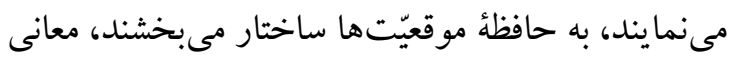
جملههاى زبان را بازنمون مى كنند و در نهايت، براى رسيدن به نتايج مختلف در فر آيند تفكّر، مورد استفاده قرار مى گيرند. دهلها ما شاهد بذيرش كستردهاى مبنى بر اين كه بازنمايى هاى غير كالبدى سنگك بناى شناخت هستند، در

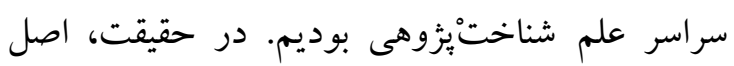

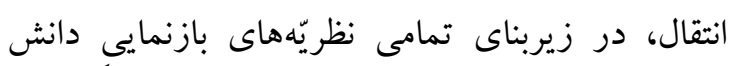

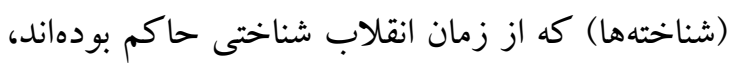
قرار دارد. اين نظريّهها عبارتاند از: نظريّهُ شبكههاى

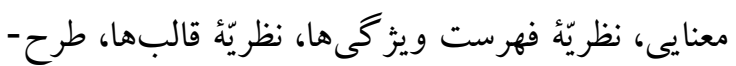

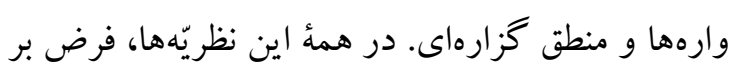
اين است كه نمادهاى غير كالبدى كه از بازنمايىهاى كالبدى منتقل مىشوند، ويز گیىها، ارتباطها و مفاهيم سازنده شناخت را نمايندگى مى كنند (بارسالو، 1999 و 2003).

2. 3 نظريّههاى جسم آكين يا كالبدى بازنمايى دانش

(شناختهها)

نظريّه هاى مربوط به دانش و معرفت، يِش از از انقلاب

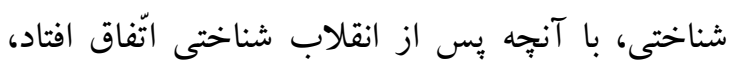
تفاوت بسيار داشتند. اكثر فلاسفهاى كه دربارةٌ دانش و معرفت نظريّهيردازى مى كردند فرضشان اين بود كه تصاوير، نقشى مركزى در بازنمايى دانش (شناختهها) دارند. تصاوير در بازنمايى دانش (شناختها)، از جنان جايگاهى برخوردار بود كه صرفاً براى تجربه گرايانى
موارد فوق، مانند نشستن بر صندلى يا ديدن صحنه اتاق

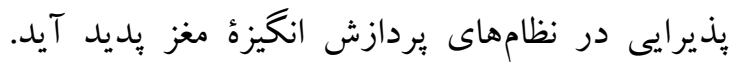

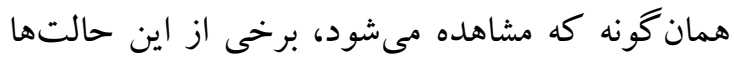

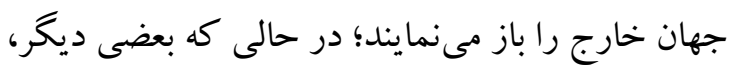

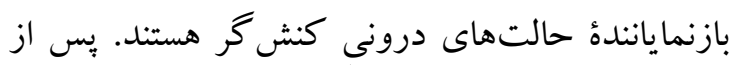

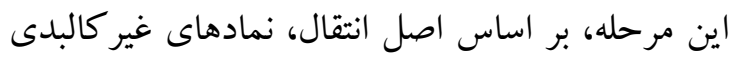

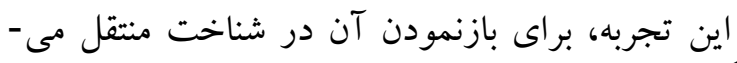

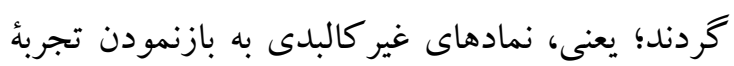

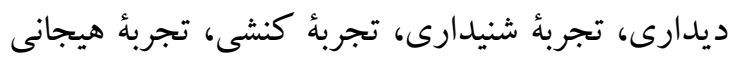
و تجربئ انخيزشى هدايت مىشوند. هنگامى كه فر آيند

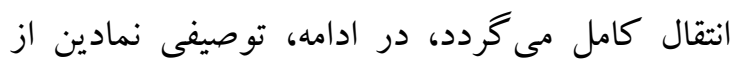
تجربه، آن را در حافظه بازنمايى مى كند. از سوى

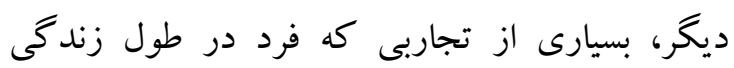
خويش با آنها مواجه مى گردد، با يكديخر مشابهاند.

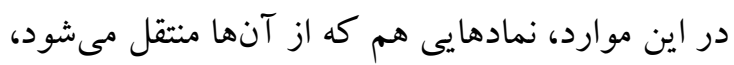

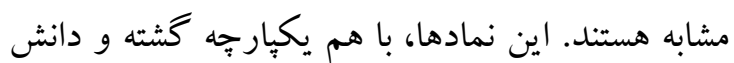
آن نوع خاصِّ موقعيّت را فراهم مى آورند. نكتئ بسيار مهم در نظريّهاى غير كالبدى بازنمايى

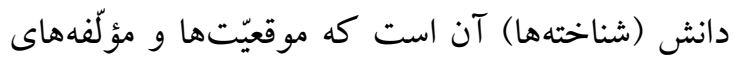
شناخت را در : بردازش مفهومى بعدى، نمادهاى

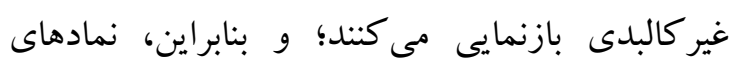

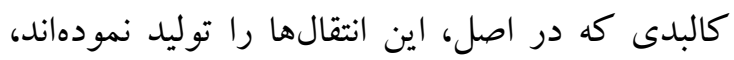

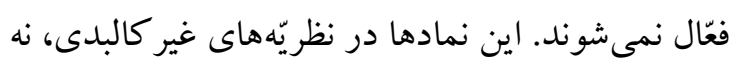

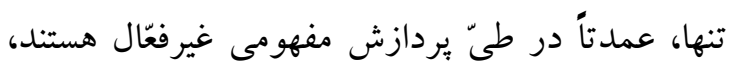

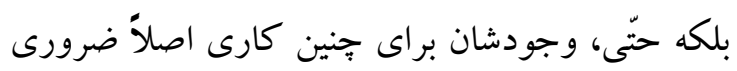

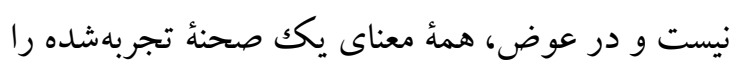
نمادهاى غير كالبدى به دوش مى كشند. براى مثال،

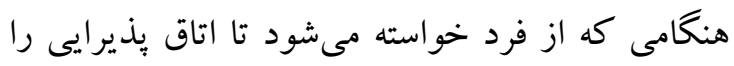
وصف نمايد، او براى اين كار، نمادهاى منتقلشده از تجربه را (كه ممكن است در قالب طرحواره' خود را نشان دهند و بازنمايندهُ اتاق يذير ايى باشد)، باز مى يابد

1- Schema 
هاى كالبدى فعّال مى شوند. آنجهه بِ از اين مرحله رخ

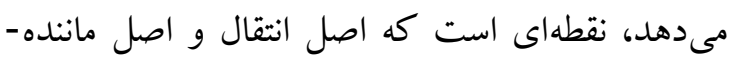
سازى در آن، از هم جدا مى گردند. در حالى كه اصل انتقال، فرضش اين است كه نمادهاى غير كالبدى براى إى إنى

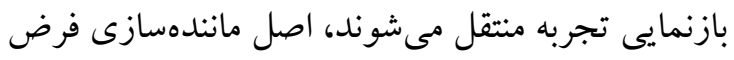

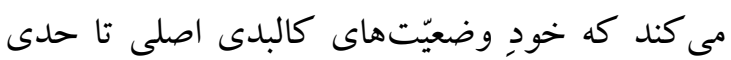

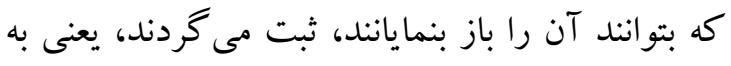

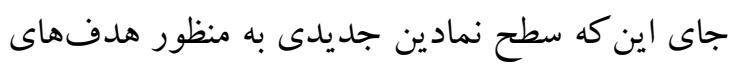
مفهومى ايجاد شود، بازنمايىهاى موجود، خودشان،

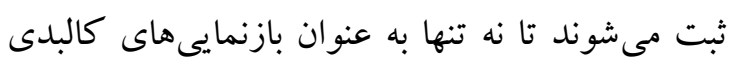

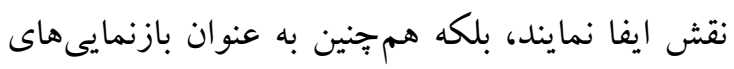
مفهومى نيز عمل نموده و در واقع، دو كار انجام دهند. شكل ظاهر و صورت اين ثبت، به طور گستردهاى و در رويكردهاى مختلف، فرق مى كند. در رويكردهاى فلسفى كلاسيك، اين گونه فرض مى كردند كه ذهن، تصاوير ذهنى را در طىّ ادراكى، براى استفادهُ بعدى در تصوّر، ذخيره مى كند. امّا در بسيارى از نظريههاى رايج

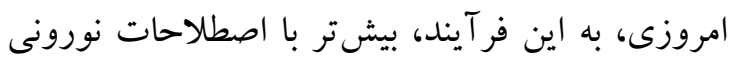

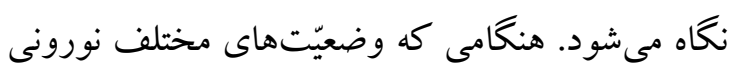
در نظامهاى كالبدى، در حين تعامل با محيط، درونى يا

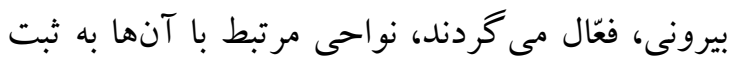
اين حالتها مى يردازند. با اين حال، صرفِ نظر از اين كه در يكك رويكرد كالبدى، ديد آهاه نورونى، شناختى

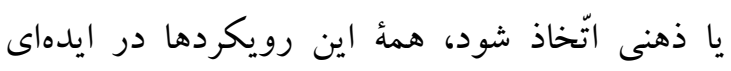
مشتركاند و آن ايده، اين است كه حالتهاى كالبدىاى كه در تجربههاى واقعى، ذخيره مى گردند، بعداً براى هدف لهاى مفهومى و ادراكى مورد استفاده واقع مىشوند. براى مثال، وقتى فردى وازٔه صندلى را

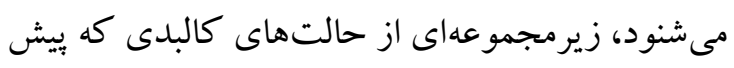

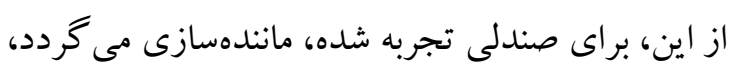
يعنى دوباره اجرا مى شود تا معناى وازه را بازنمايى كند.

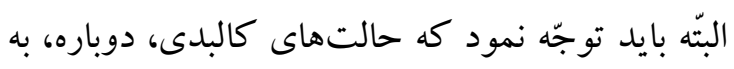

جون لاكك و بار كلى' مهم نمىنمودند، بلكه براى فطرت گرايانى مانند كانت و ريد بن نيز از درجهُ اهميّت بالايى برخوردار بودند. البّته، از جهات مختلف نظرات

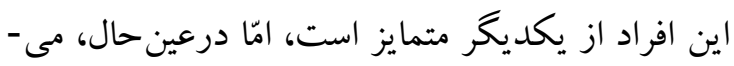

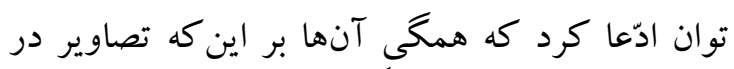
بازنمايى دانش (شناختهها)، نوعى نقش ايفا مى كنند، همنظر بودند. در ادامهُ انقلاب شناختى، نظريّهِيردازان،

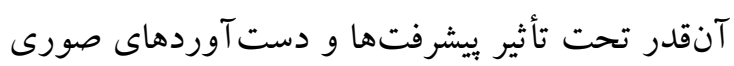

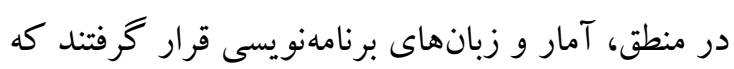

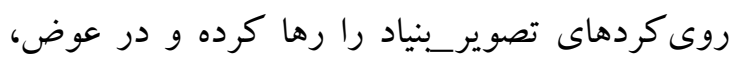
روى كردهاى غير كالبدى را كه شرح داده شد، اتّخاذ

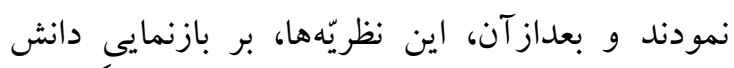

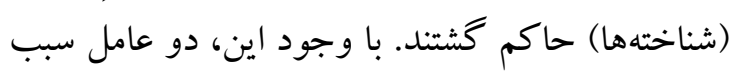

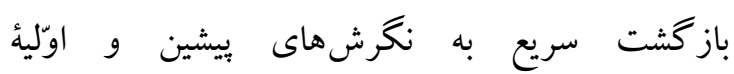

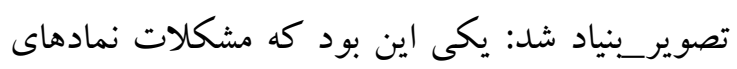

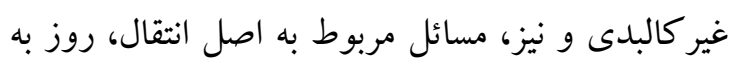

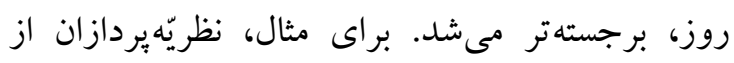

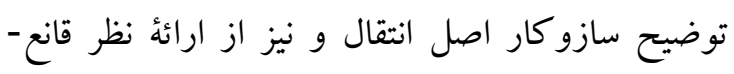

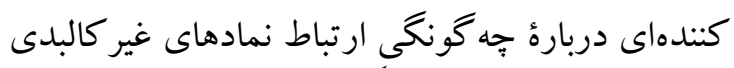
با ادراكك و كنش، ناتوان ماندند. به علاوه اين كه شاهد تجربى قوى نيز، مبنى بر وجود نمادهاى غير كالبدى در مغز يافت نشد. عامل دوم، روى كردهاى نورونى بودند كه به طور فزايندهاى بر وجود نظامهاى كالبدى در درو رون

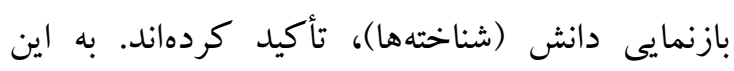

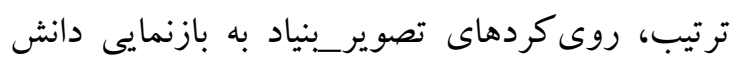

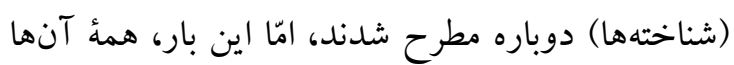
در اصلى كه اصل مانندهازى نام گرفته است، مشتر كى بودند. اصل مانندهازى فرض را بر اين مى كذارد

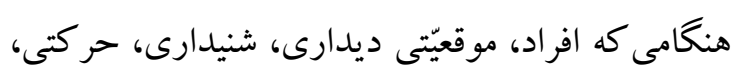
لمسى، هيجانى و انكيزشى را تجربه مى كنند، حالت1-Berkeley
2- Reid 
كالبدى براى استفادهُ بازنمون بعدى، ثبت مى گردند، نه

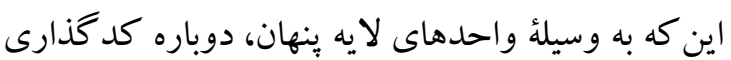
شوند. نظريّههاى نورونى تصويرسازى نيز، به طور وسيعى، اين فرض را يذيرفتهاند كه تصوير ذهنى، انجام

$$
\text { مجدّد نورونى حالتِ كالبدى است. }
$$

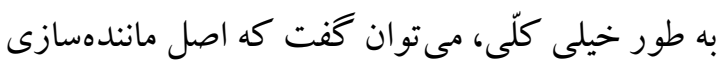

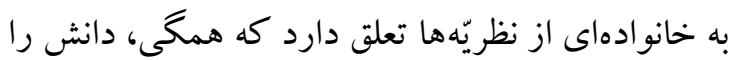
در بافت فيزيكى، بايهمند مى كنند. بر اساس اين نظريّه-

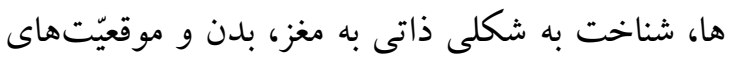
محيطى كه در آن قرار دارد، وابسته است و مستقل از آنها وجود ندارد. نظريّههاى متفاوت، بر جنبهاى مختلف بافت فيزيكى در بازنمايى دانش (شناختهها)

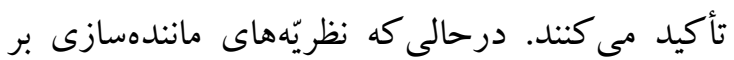
نقش نظامهاى كالبدى تمركز نمودهاند، نظريّههاى جسم آكين، بيشتر، نقش حالتهاى بدنى را مورد توجّه قرار دادهاند و نظريّههاى موقعيّى نيز بر نقش موقعيّتهاى محيطى تكيه كردهاند. امّا مهم است كه بدانيم در بازنمايى دانش (شناختها)، هر سه، يعنى،

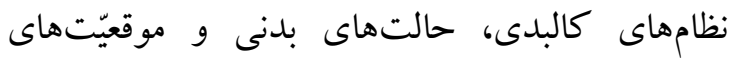
محيطى، نقش مهمّى ايفا مىنمايند. براى راحتى كار،

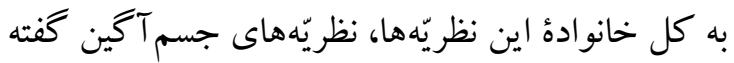
مىشود. امّا بايد به خاطر بسباريم جسم آكينى، به طور

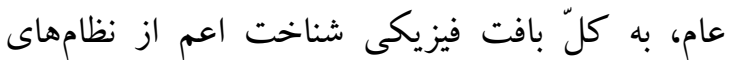
كالبدى، حالتهاى بدنى و موقعيّت هاى محيطى، اشاره

$$
\text { دارد (بارسالو، } 1999 \text { و 2003). }
$$

\section{2. 3 شواهد تجربى دربارؤ مانندهازى}

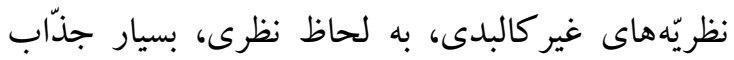

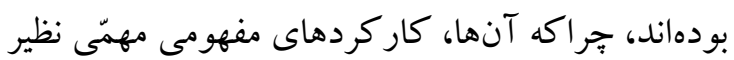
تمايز نوع و نقش، استنتاج مقولهاى، زايايى و نيز كزارهها را مدلسازى مى كنند. به علاوه، اين نظريّهها، همجزنين، قابل فرمولبندى بوده و در رايانه هم از امكان

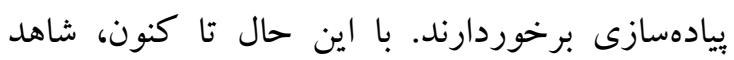

طور كامل اجرا نمى گردند و بلكه در عوض، اين حالتها تنها تا حدّى و قسمتى مانندهسازى مى شوند، به كونهاى كه اطّلاعات بازنمايىشده، نسبتاً عارى از جزئّات، ناكامل و احتمالاً تحريف بـده بوده و ممكن است سوىمندى داشته باشند. با وجود اين، آنها بازنمايىهاى سطح شناختىاى را مهيّا مىنمايند كه زبان، انديشه و حافظه را حمايت مى كنند. در اين نظريّه، ايدهُ صندلى به وسيلة نمادهاى غير كالبدى، از

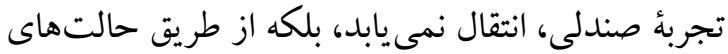
كالبدى كه در حين تعامل با صندلى، تجربه شده است،

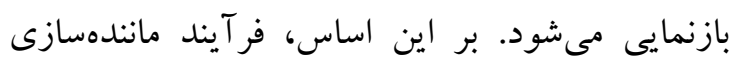
زيربناى دانش در طيف فعّالِّتهاى شناختى قرار مى -

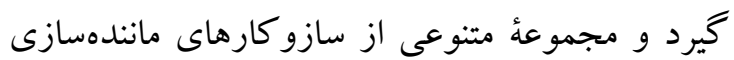
كه نظام بازنمايى مشتركى را به اشتراكى دارند، از اين

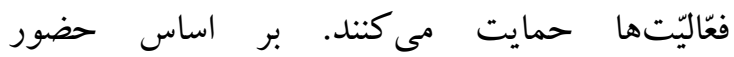
سازو كارهاى مانندهسازى، به همر اه يردازشهاى متنوع شناختى، است كه مانندهازى، صورت هستهاى محاسبات مغزى را فراهم مىنمايد. تصويرسازى ذهنى، شناختهشهترين نوع اين سازو كارهاى مانندهازى

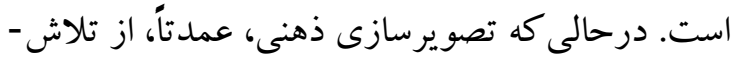
هاى عمدى براى ساخت بازنمايىهاى آكاهانه در حافظهُ كار آيند 'ناشى مى شود، به نظر مىرسد صورت -

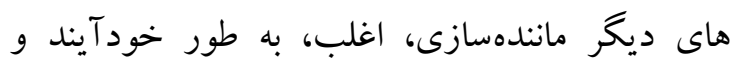
نا كآهانه و خارج از حافظة كار آيند، فقّال مى گردند. اصل ماندهسازى به طريقى در رويكردهاى گوناگون و گستردهاى واردشده است. به عنوان مثال، در نظرئ.

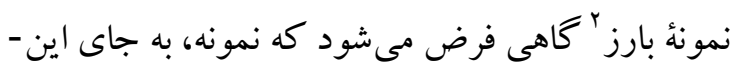
كه توصيفى غير كالبدى باشد، ذخيره حالتى كالبدى، بهو

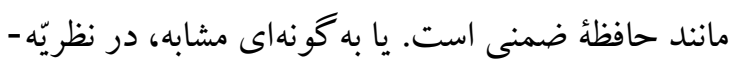

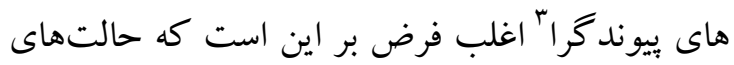

1- Working memory

2- Exemplar

3- Connectionism 
بازنمايى دانش و معرفت، شبيه به نخرش هاى مانندهسازى در عصر حاضر است. در ابتداى قرن بيستم، رفتاركرايان و از جملهُ آنها،

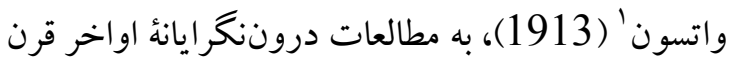
نوزدهم حمله كرده و تصويرسازى را به همراه بعضى

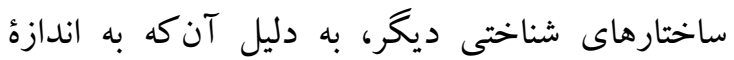
كافى علمى نبودند، از روانشناسى طرد كردند.

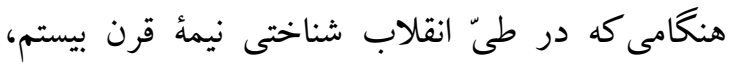

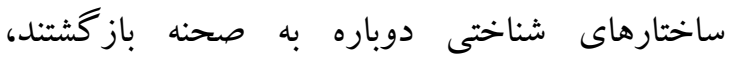

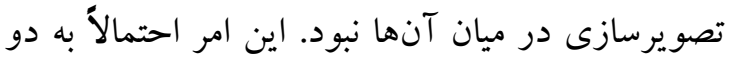
دليل رخ داد: يكى اين بود كه شناختُْْروهان جديد، حمله هاى واتسون به تصوير سازى را به خاطر داشتند و ترجيح دادند كه از قرارگرفتن در معرض انتقادهاى مشابه، اجتناب ورزند؛ و ديكر اين كه آنها شيفته صورتبندىهاى جديد بازنمايىاى شده بودند كه به واسطة بيشرفت روزافزون در منطق، زبانشناسى، آمار و علوم رايانه القاء شده بود. درنتيجه، نظريّهاى شناخت

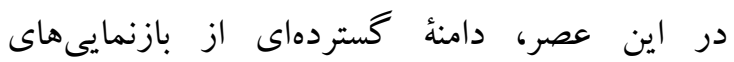
غير كالبدى را اتّخاذ نمودند كه شامل فهرست كردن ويز گى ها، شبكههاى معنايى و قالبهاى معنايى مى شد.

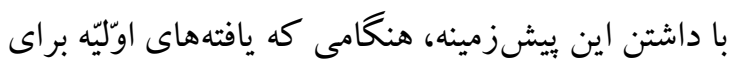

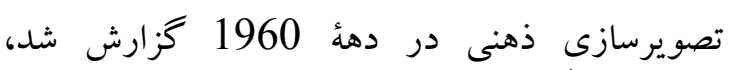

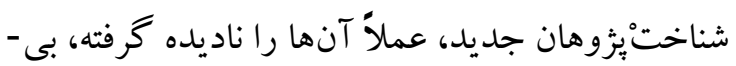
اعتبار خواندند. با وجود اين، شواهد نورونى و رفتارى براى تصويرسازى، آنجنان قوى بود كه تصويرسازى،

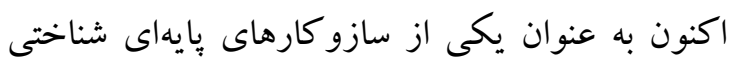

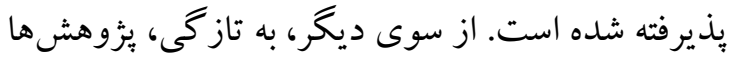
در شناخت, يايهمند، نظريّهايى را كه در طىّ انقلاب شناختى برخاسته بودند و در آن انقلاب ريشه دارند، به شيوههاى متفاوت به جالش كشيدهاند. يكى از اين جالشها نبود شواهد تجربى قابل توجّه بر حضور
تجربى قوىاى بر وجود آنها به دست نيامده است. امّا، براى بازنمايىهاى مبتنى بر مانندهازى در حافظهُ كار آيند، حافظةٌ بلندمدّت، زبان و انديشه، شواهد تجربى غيرمستقيم فراوانى كه عمدتاً ناشى از مطالعات

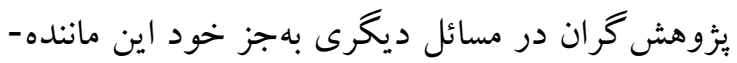
سازىها بوده، جمع آورى شده است. اين شواهد، بِايهاى محكم را براى نظريّهاى كالبدى يى مىريزد

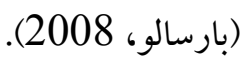

\section{4. نظريّه هاى شناخت بِ بايهمند}

منظور از نظريّههاى بايهمند، آن دسته از نظريّهـها دربارهُ شناخت است كه نظريّهاى معيار شناخت را كه بر مبناى نمادهاى غير كالبدى هستند، رد مى كند و نسبت به آنها واكنش منفى نشان مىدهد. در عوض، اين مادي هين نظريّهها، نخرش هايى را نسبت به سازو كارهاى شناخت

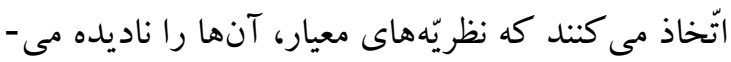
كيرند؛ از آن جمله: مانندهازى يا تصويرسازى، كنش موقعيّت و حالتهاى بدنى؛ و در حقيقت، بايهٔ شناخت را در اينها مىدانند. اخرجه اغلب اين نظريّه توصيفىاند، آنها، فرضيّههايى را كه قابل آزمودن هستند و در يُزوهشهاى تجربى به آنها بردداخته مى -

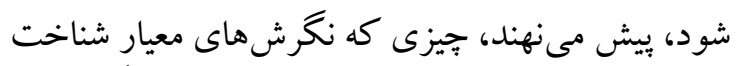
از آن بى.بهرهاند. هدف نهايى و مهم بيش روى اين نظريّها، دادهيردازى و صورتبندى اين نظريّههاست، جيزى كه نظريّهاى معيار در آن زمينه، برتر هستند

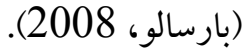

\section{4 خاستعاههاى شناخت يِايهمند}

برخلاف آنجه در بسيارى از نوشتارها تأكيد مىشود،

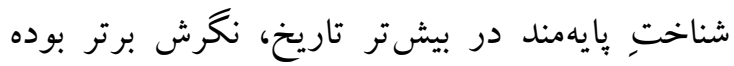

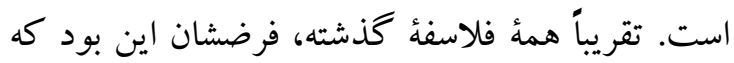
بازنمايىهاى كالبدى و تصويرسازى ذهنى، دانش و

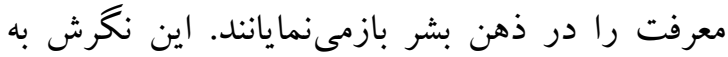


يردازش مفهومى بر اساس مانندهازى يا فعّالسازى مجدّد نورونى مربوط به حالتهاى بدنى صورت مى - ملى

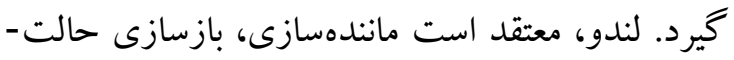
هاى ادراكى، حر كتى و درونى حاصل از تجربهُ فرد با بال جهان خارج، بدن و ذهن را امكانيذير مىسازد. وقتى ما تجربهاى بيدا مى كنيم، مغز يكك بازنمايى جندوجهى بهى بهى بيدا مى كند كه در حافظه ذخيره مىشود. بعدها هر

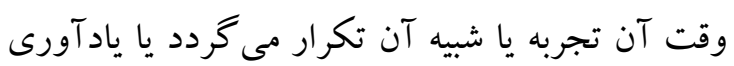
آن از طريق قراين مختلف اتْفاق مىافتد، كلٍ آن آن بازنمايى، فُّال مىشود (قاسمزاده، 1393، ص صرئ

2. 4 تصوّرات نادرست امّا متداول دربارهُ شناخت يَايهـ

مند

از آنجا كه رويكردهاى بايهمند كنونى به شناخت،

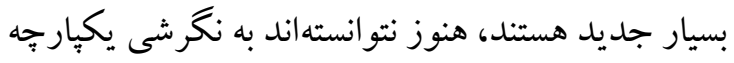
دست يابند. علاوه بر اين، خود همين رويكردهاى متنوّع نيز به صورت محاسباتى يا صورى مشخص نشدهاند. از اين رو، ابهامها دربارهُ اين نظريّها وجود

دارند و تصوّرات نادرست نيز دور از انتظار نيست.

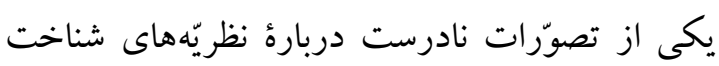
پايهمند اين است كه آنها، اغلب، كاملاً تجربى در نظر گرفته شده و بنابراين، گويى كه با فطرت گُرايى در

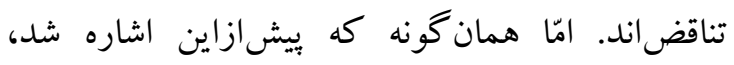

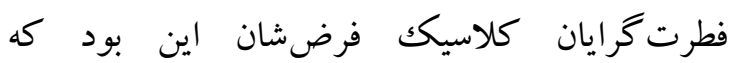
تصويرسازى، عهدهدار نقشى مركزى در بازنمايى دانش (شناختهها) است. در واقع، هيج دليلِ قبلى، براى اين كه مانندهازى بايهُ زَنتيكى قوى نداشته باشد، وجود ند ندارد. مشاركت زنتيكى، در بيشتر موارد، به نظامهاى كالبدى و نظامهاى حافظه كه كار ثبت و يردازش

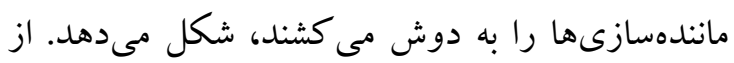

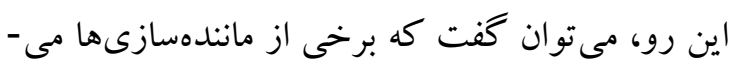

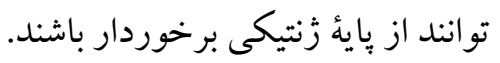

نمادهاى غير كالبدى در شناخت است. يزوهش ها نشان دادهاند كه درواقع، اگر نمادهاى غير كالبدى به طور وسيعى، در نظريّهاى مختلف مورد يذيرش واقع شدهاند، اين، به خاطر حمايت شواهد تجربى نبود، بلكه،

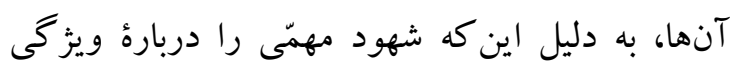
نمادين شناخت ثبت كرده بودند، به نحوى كه بتوانند در هوش مصنوعى، دادهيردازى شوند و صورتكرايىهاى قدرتمند و و عالىاى را براى بازنمايى اطّلاعات، آماده مى نمودند و از اينرو، با استقبال مواجه كشتند. جالش ديخر اين بود كه نظريّههاى غير كالبدى

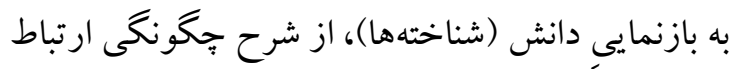

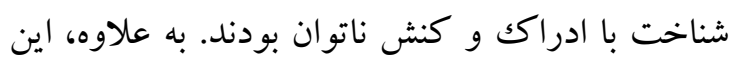

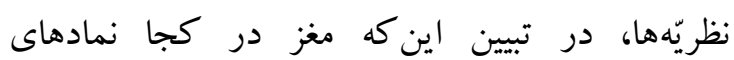
غير كالبدى را ذخيره مى كند و اين كه جه گونه اين نمادها با اصول نورونى محاسبات همراه مىشوند،

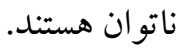

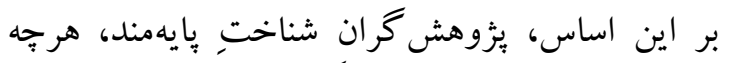

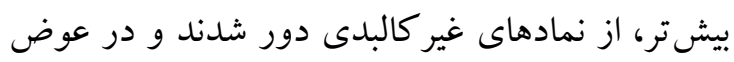
به مانندهازى كنش موقعيّت و حالتهاى بدنى روى آوردند. اين :ثزوهش كران، در بسيارى از جنبهاريا، فرضيّة فيلسوفان كلاسيك را كه مبتنى بود بر اين كه بردي بازنمايىهاى كالبدى در مركز شناخت قرار دارند، دوباره مدّ نظر قرار داده، آن را در بافتهاى متأخّر روانشناسى، علم شناختُْْزوهى و علم عصبْيْايه بازآفريدند و نيز بر بازنمايىهاى نورونى به شكل كالبدى تمركز نموده و كمتر به تصويرسازى آكاهانه يرداختند (بارسالو، 2008). براى مثال، لندو' (2010)

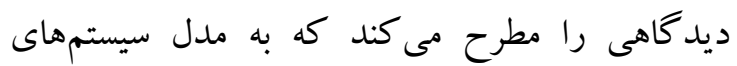
نمادين ادراكى شهرت داشته و شباهت زيادى نيز به نظريّهُ بارسالو (2008) دارد. نظريّهُ او بانفوذترين نظريّه دربارهُ شناخت اجتماعى است. بر طبق اين نظريّه،

1- Landau 
برخاستهاند. اين نظريّهها، از يككسو، واكنش هاى منفى بودند به نظريّهاى غير كالبدى نحوى كه در انقلاب

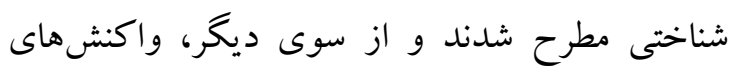

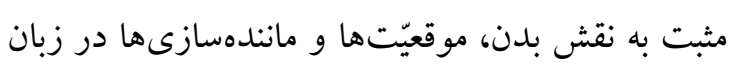

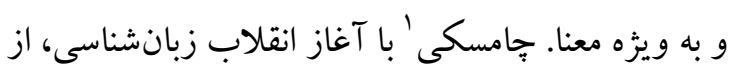
نخستين سالهاى نيمهُ دوم قرن بيستم با معرّفى مفاهيم

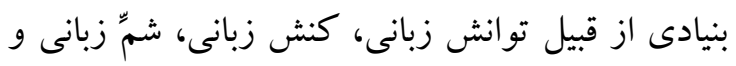

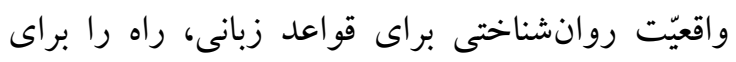

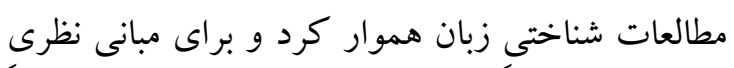

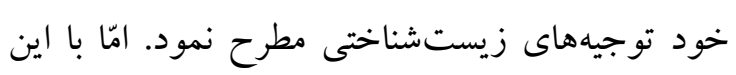

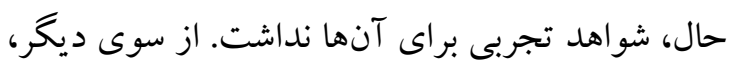

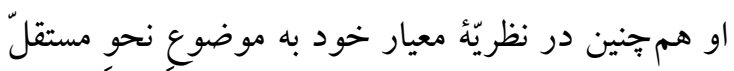

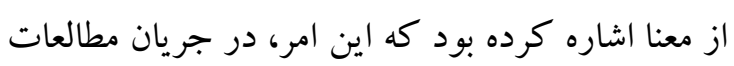
انقلابى زبانشناسى جامسكى، از سوى ليكاف و بعضى آنى

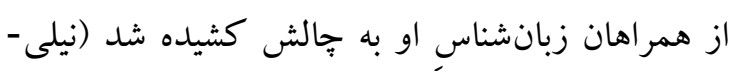
يور، 1394). علاوه بر اين، ليكاف و به همراه او،

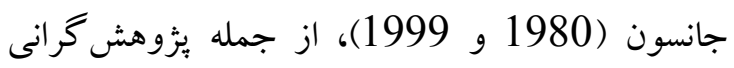
بودند كه ادّعا كردند مفاهيم انتزاعى، به طور استعارى در دانش (شناختهها) جسم آكين و وابسته به موقعيّت،

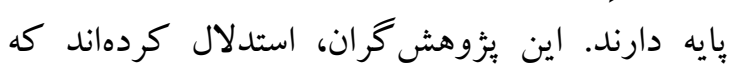

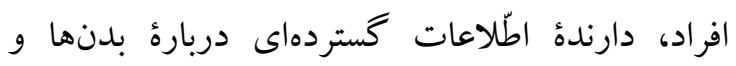
موقعيّتهاشان هستند و مفاهيم انتزاعى نيز به طور

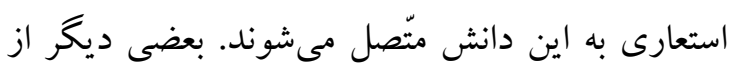

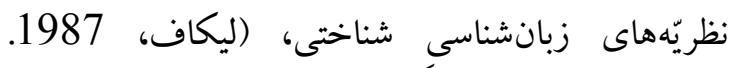

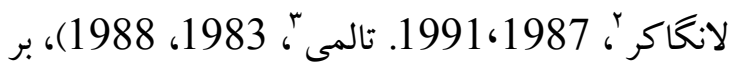
اين باورند كه نحو و معناشناسى زبانهاى طبيعى، در

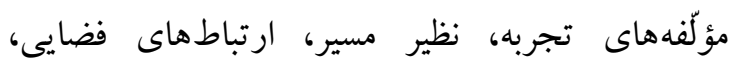
يردازشها و نيروها پايه دارند. به علاوه، زبانشناسان

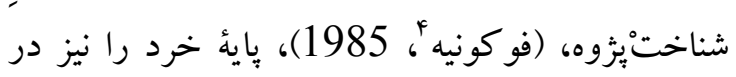

1- Chomsky

2- Langacker

3- Talmy

4- Fauconnier
تصوّر نادرست ديخرى كه نسبت به نظريّهاى شناخت يايهمند متداول است، اين است كه اين نظريّهها، در موارد بسيارى، به شكلى در نظر گرفته مىشوند كه

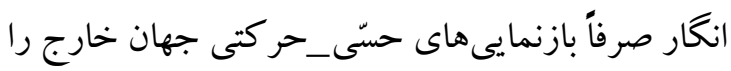

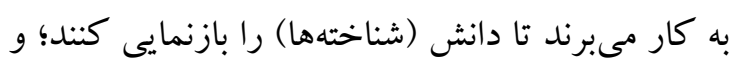
بر اين اساس، نتيجه گرفتهاند كه نظريّهاى بايهمند نمى تواند مفاهيم انتزاعى را كه در جهان خارج بايه

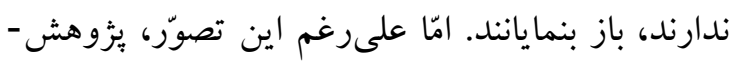

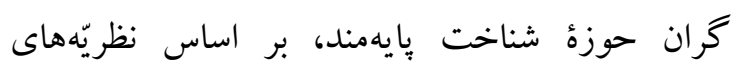
تجربه گرايان كلاسيك، استدلال كردهاند كه حالت

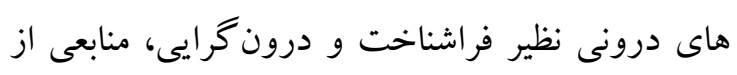

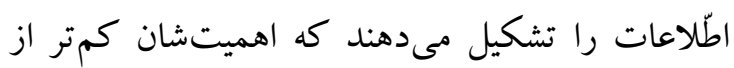
تجربهُ بيرونى نيست. اين نظريّه بِردازان، ابراز مى كنند

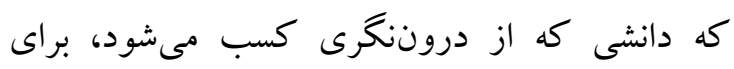
بازنمايى مفاهيم انتزاعى، مىتواند مفيد باشد.

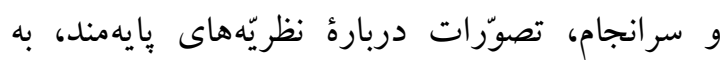
كونهاى است كه گويى اين نظريّها ضرورتاً به حالت هاى بدنى يا مانندهسازىهايى كه تمام و كمال، تجربه را بازآفرينى مى كنند، وابسته هستند. امّا محقّقان اين عرصه، خود، جنين فرضى ندارند. آنها مى گُويند

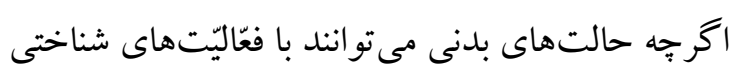

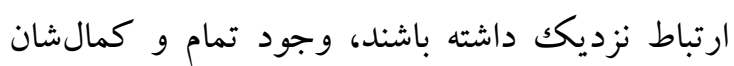
براى آنها ضرورى نيست. درست است كه مانندهسازى، در بازنمايى دانش (شناختهها) در اين نظريّها نقش مركزى دارد، امّا به ندرت، تجربهها را به طور كامل بازسازى و بازخلق مىنمايد. در عوض، ماننده-

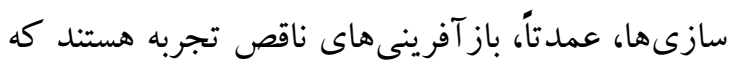
مى تواند هم خطا داشته باشند و هم سوى مندى بر آنها سايه افكنده باشد (بارسالو، 2008). 5. نظريّه هاى زبانشناسى شناختى

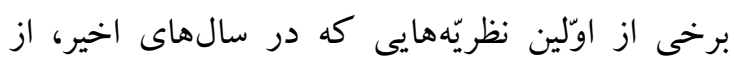

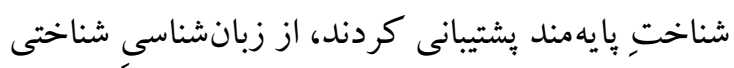


روش هاى متفاوتى براى بازنمايى هستند كه هر يكك، از معايب و محاسن خاص خود برخوردار بوده و براى رونى شرايطى خاص مناسباند.

تجربه مىدانند. عدّهاى ديخر از اين يثوهش گرخان

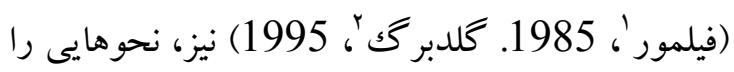
كه قالبها و ساختها را به كار مىبرند، گُشترش دادند تا ساختار موقعيّتها را ثبت كنند (بارسالو، 2008). نقش شناخت بايهمند در نظريّههاى زبانشناسى، موضوع جالبى است كه بايد جداكانه به آن

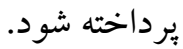

6. نتيجه

برخلاف آنجه كه از زمان انقلاب شناختى درباره بازنمايىهاى غير كالبدى در نظام شناختى انسان مطرح

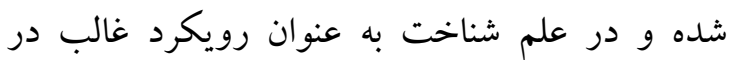
بازنمايى دانش و معرفت معرّفى گشته، اين شناخت يايهمند است كه در بيشتر تاريخ كذشته، نگرش برش برتر بوده است. جراكه شناخت بِيهمند ريشه در نظامهاى كالبدى بازنمايى دانش (شناختهها) دارد و تقريباً اكثر

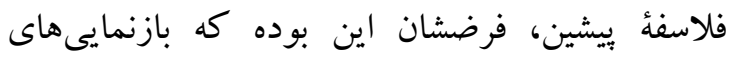
كالبدى و تصويرسازىهاى ذهنى كه نسبتاً مشابه ماندهسازىها در نظريهُ شناخت, بِايهمند هستند، دانش و معرفت را در ذهن بشر بازمىنمايانند. از سوى ديخر،

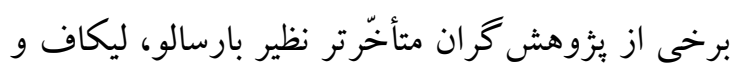
جانسون نيز در يثوهشهاى خود نشان دادهاند كه رويكردهاى غير كالبدى به بازنمايى دانش (شناخته ها)،

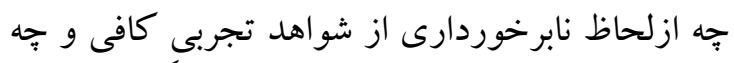

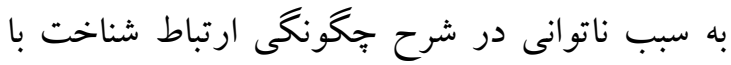
ادراك و كنش، با جالشى جدّى مواجهاند. باينحال، به نظر مىرسد همان گونه كه رومِلهارت اشارهكرده است، شايد تفاوتهاى ميان اين دو نظام بازنمايى، بيش

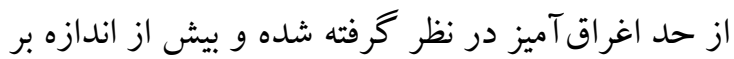
آنها تأكيد شده است. در واقع و بر اساس نظر رومِلهارت، مىتوان كفت اين نظامهاى بازنمايى، 


\section{References}

Barsalou, L.W., 2008. Grounded Cognition. Annual Review of Psychology, 59, pp. 617-45.

Barsalou, L.W., 1999. Perceptual symbol systems. Behavioral and Brain Sciences, 22, pp. 577-660.

Barsalou, L.W., 2003. Situated simulation in the human conceptual system. Language and cognitive processes, 18 (5/6), pp. 513562.

Cohen, G. and Conway, M., 2008. Memory in the real world. Psychology Press.

Friedenberg, J. and Silverman, G., 2006. Cognitive science: An introduction to the study of mind. Translated from Persian by Mohsen Oftadehal. et al. Sage Publication, Inc.

Ghassemzadeh, H., 2014. Cognition: Disembodiment, embodiment, and syneasthesia. Brain, Cognition \& Behavior, Acollection of seminar papers, Book 1, pp. 73-113. [Persian]

Ghassemzadeh, H., 2004. Vygotsky`s mediational psychology: A new conceptualization of culture, signification and metaphor. Language Sciences, 27, pp. 281-300.

Ghassemzadeh, H., 2006. Vygotsky and motivation for speech. Chista, 128-129, pp. 669-685. [Persian]

Ghassemzadeh, H. Posner, M. and Rothbart, M., 2013. Contribution of Hebb and Vygotsky to an

integrated science of mind. Journal of the History of the Neurosciences: Basic and Clinical Perspectives, 22, pp. 292-306.

Kiefer, M. and Pulvermuller, F., 2011. Conceptual representations in mind and brain: theoretical

developments, current evidence and future directions. Cortex, pp. 805-825.

Nilipour, R., 2015. Language implanation in the brain: inherent or acquired. Brain, Cognition \& Behavior, Acollection of seminar papers, Book 2, pp. 9-34. [Persian]

Rumelhart, D.E. and Norman, D.A., 1983. Representation in memory. Cognitive Science Laboratory, Center for Human Information Processing, University of California, San Diego. 